\title{
Gene expression during THP-1 differentiation is influenced by vitamin D3 and not vibrational mechanostimulation
}

\author{
Theodoros Simakou ${ }^{1,2}$, Robin Freeburn ${ }^{1}$, Fiona Henriquez ${ }^{\text {Corresp. } 1}$ \\ ${ }^{1}$ School of Health and Life Sciences, University of West of Scotland, Paisley, United Kingdom \\ 2 Institute of Infection, Immunity and Inflammation, University of Glasgow, Glasgow, United Kingdom \\ Corresponding Author: Fiona Henriquez \\ Email address: fiona.henriquez@uws.ac.uk
}

Background: In injury or infection, monocytes migrate into the affected tissues from circulation and differentiate into macrophages which are subsequently involved in the inflammatory responses. Macrophage differentiation and activation have been studied in response to multiple chemokines and cytokines. However, mechanical, and physical stimuli can also influence macrophage differentiation, activation, cytokine production, and phagocytic activity. Methods: In this study, the macrophage differentiation from THP-1 monocytes was assessed upon the stimulation with 1,25-dihydroxyvitamin D3 and $1000 \mathrm{~Hz}$ vibrations, using qPCR for quantification of transcript expression. Vitamin D binds the vitamin D receptor (VDR) and subsequently modulates the expression of a variety of genes in monocytes. The effects of the $1000 \mathrm{~Hz}$ vibrational stimulation, and the combined treatment of vitamin D3 and $1000 \mathrm{~Hz}$ vibrations were unknown. The differentiation of macrophages was assessed by looking at transcription of macrophage markers (e.g., CD14, CD36), antigen presenting molecules (e.g., HLA-DRA), transcription factors (e.g., LEF-1, TCF7L2), and mechanosensors (e.g., PIEZO1 and PKD2). Results: The results showed that vitamin D3 induced THP-1 macrophage differentiation, which was characterized by upregulation of $C D 14$ and $C D 36$, downregulation of HLA-DRA, upregulation of the PKD2 (TRPP2), and an inverse relationship between TCF7L2 and LEF-1, which were upregulated and downregulated respectively. The $1000 \mathrm{~Hz}$ vibrations were sensed from the cells which upregulated PIEZO1 and TCF3, but they did not induce expression of genes that would indicate macrophage differentiation. The mRNA transcription profile in the cells stimulated with the combined treatment was comparable to that of the cells stimulated by the vitamin only. The $1000 \mathrm{~Hz}$ vibrations slightly weakened the effect of the vitamin for the regulation of CD36 and HLA-DMB in the suspension cells, but without causing changes in the regulation patterns. The only exception was the upregulation of TCF3 in the suspension cells, which was influenced by the vibrations. In the adherent cells, the vitamin D3 cancelled the upregulating effect of 
the $1000 \mathrm{~Hz}$ vibrations and downregulated TCF3. The vitamin also cancelled the upregulation of PIEZO1 gene by the $1000 \mathrm{~Hz}$ vibrations in the combined treatment. Conclusion: The mechanical stimulation with $1000 \mathrm{~Hz}$ vibrations resulted in upregulation of PIEZO1 in THP-1 cells, but it did not affect the differentiation process which was investigated in this study. Vitamin D3 induced THP-1 macrophage differentiation and could potentially influence $M 2$ polarization as observed by upregulation of $C D 36$ and downregulation of HLA-DRA. In addition, in THP-1 cells undergoing the combined stimulation, the gene expression patterns were influenced by vitamin D3, which also ablated the effect of the mechanical stimulus on PIEZO1 upregulation. 
1 Gene expression during THP-1 differentiation is influenced by vitamin D3 and not 2 vibrational mechanostimulation

3

4

Theodoros Simakou ${ }^{1,2}$, Robin Freeburn², Fiona L. Henriquez ${ }^{2}$,

${ }^{1}$ University of Glasgow, Institute of Infection, Immunity and Inflammation, Glasgow, Lanarkshire, United Kingdom

${ }^{2}$ University of West of Scotland, School of Health and Life Sciences, Paisley, Renfrewshire, United Kingdom

Corresponding Author:

Fiona L. Henriquez

High Street, Paisley, Renfrewshire, PA1 2BE, United Kingdom

Email address: fiona.henriquez@uws.ac.uk

\section{Abstract}

Background: In injury or infection, monocytes migrate into the affected tissues from circulation and differentiate into macrophages which are subsequently involved in the inflammatory responses. Macrophage differentiation and activation have been studied in response to multiple chemokines and cytokines. However, mechanical, and physical stimuli can also influence macrophage differentiation, activation, cytokine production, and phagocytic activity.

Methods: In this study, the macrophage differentiation from THP-1 monocytes was assessed upon the stimulation with 1,25-dihydroxyvitamin D3 and $1000 \mathrm{~Hz}$ vibrations, using qPCR for quantification of transcript expression. Vitamin $D$ binds the vitamin $D$ receptor (VDR) and subsequently modulates the expression of a variety of genes in monocytes. The effects of the $1000 \mathrm{~Hz}$ vibrational stimulation, and the combined treatment of vitamin D3 and $1000 \mathrm{~Hz}$ vibrations were unknown. The differentiation of macrophages was assessed by looking at transcription of macrophage markers (e.g., $C D 14, C D 36$ ), antigen presenting molecules (e.g., HLA-DRA), transcription factors (e.g., LEF-1, TCF7L2), and mechanosensors (e.g., PIEZO1 and PKD2).

Results: The results showed that vitamin D3 induced THP-1 macrophage differentiation, which was characterized by upregulation of $C D 14$ and $C D 36$, downregulation of HLA-DRA, upregulation of the PKD2 (TRPP2), and an inverse relationship between $T C F 7 L 2$ and $L E F-1$, which were upregulated and downregulated respectively. The $1000 \mathrm{~Hz}$ vibrations were sensed from the cells which upregulated PIEZO1 and TCF3, but they did not induce expression of genes that would indicate macrophage differentiation. The mRNA transcription profile in the cells stimulated with the combined treatment was comparable to that of the cells stimulated by the vitamin 
41 only. The $1000 \mathrm{~Hz}$ vibrations slightly weakened the effect of the vitamin for the regulation

42 of $C D 36$ and $H L A-D M B$ in the suspension cells, but without causing changes in the

43 regulation patterns. The only exception was the upregulation of TCF3 in the suspension

44 cells, which was influenced by the vibrations. In the adherent cells, the vitamin D3 cancelled the upregulating effect of the $1000 \mathrm{~Hz}$ vibrations and downregulated TCF3.

The vitamin also cancelled the upregulation of PIEZO1 gene by the $1000 \mathrm{~Hz}$ vibrations in the combined treatment.

Conclusion: The mechanical stimulation with $1000 \mathrm{~Hz}$ vibrations resulted in upregulation of PIEZO1 in THP-1 cells, but it did not affect the differentiation process which was investigated in this study. Vitamin D3 induced THP-1 macrophage differentiation and could potentially influence M2 polarization as observed by upregulation of $C D 36$ and downregulation of HLA-DRA. In addition, in THP-1 cells undergoing the combined stimulation, the gene expression patterns were influenced by vitamin D3, which also ablated the effect of the mechanical stimulus on PIEZO1 upregulation.

\section{Introduction}

58

59

60

61

62

63

64

65

66

67

68

69

70

71

72

73

74

75

76

77

78

79
Macrophages play important roles in health and disease through phagocytosis of pathogenic microorganisms, by releasing inflammatory mediators, by inducing and maintaining inflammation, and by removing apoptotic cells and repairing tissues (Gordon, 2007, Mosser and Edwards, 2008). Tissue-resident macrophages, derived from the yolk sac at the embryonic stage, are replicated in tissues to maintain cell number, and have different morphology and function depending on the tissue where they reside (Lavin et al., 2015). However, in the case of tissue injury or infection, monocytes derived from bone marrow circulating in peripheral blood, migrate to the affected tissues where they differentiate into macrophages, and are subsequently involved in the inflammatory response (Shi and Pamer, 2011).

THP-1 cells are human immortalized monocytes derived from acute monocytic leukemia and have been extensively used to study macrophage differentiation, functions, signaling pathways, and nutrient and drug transport (Chanput, Mes and Wichers, 2014, Bosshart and Heinzelmann, 2016, Nurminen, Seuter and Carlberg, 2019). In this study we investigated the THP-1 responses towards stimulation with vitamin D3 (1,25dihydroxyvitamin D3), $1000 \mathrm{~Hz}$ nanovibrations or both, in order to study the expression of genes that could indicate differentiation or mechanosensitivity changes in these cells. In the following text, the combined treatment refers to the combination of $50 \mathrm{nM}$ vitamin D3 and $1000 \mathrm{~Hz}$ vibrations. The cell responses were investigated separately in adherent and suspension THP-1 monocytes upon each stimulation, to avoid averaging results for both the cell types within the same population and consider their differences (Supplemental Figure 2). 
80 Vitamin $\mathrm{D}$ has been shown to promote monocyte differentiation into macrophages and 81 targets multiple genes (Nurminen, Seuter and Carlberg, 2019). The active form of 82 vitamin $\mathrm{D}, 1,25$-dihydroxyvitamin $\mathrm{D} 3$, is a lipophilic molecule which easily passes 83 through biological membranes and binds with high-affinity to the receptor and 84 transcription factor vitamin $\mathrm{D}$ receptor (VDR), which is primarily located in the nucleus 85 (Haussler et al., 2013). The activation of vitamin $D$ target genes is explained by the 86 chromatin model (Nurminen, Seuter and Carlberg, 2019). The ligand-activated VDR 87 molecules bind to a wide variety of enhancer regions that carry suitable binding motifs and are located within accessible chromatin. With the help of pioneer factors, such as PU.1, CEBPA, and GABPA, VDR increases the accessibility of chromatin at and around these enhancer regions (Seuter, Neme and Carlberg, 2017, 2018, Nurminen et al., 2019). In THP-1 cells, 1,25-dihydroxyvitamin D3 stimulation significantly affects the binding strength of transcription factor CTCF to topologically associating domain (TAD) anchors, which results in about 600 TADs becoming sensitive to vitamin D (Neme, Seuter and Carlberg, 2016). Looping of activated DNA-bound VDR to a transcription start site (TSS) at these promoter regions results in increased chromatin accessibility as well as of H3K27ac and H3K4me3 marks (Seuter, Neme and Carlberg, 2016, Nurminen et al., 2019). All these vitamin D-triggered changes in the local chromatin structure at enhancer and promoter regions finally lead to the activation of RNA polymerase II assembled on the respective TSSs and the start of mRNA synthesis. The vitamin may also affect gene expression by increasing the expression and the activity of transcription factors other than VDR, such as BCL6, NFE2, POU4F2, and ELF4 (Nurminen et al., 2015).

The effects of vitamin D have been studied in the context of macrophage differentiation from monocytes, but they are also extended into the effector macrophage responses (Hewison, 2010). In fact, normal human macrophages are able to synthesize 1,25dihydroxyvitamin D3 when stimulated with interferon gamma (IFNy) (Phillip Koeffler et al., 1985). The vitamin $D$ is involved in the regulation of $T$ cell and macrophage effector functions, primarily via localized autocrine or paracrine synthesis of 1,25dihydroxyvitamin D3 from its precursor 25-hydroxyvitamin $D_{3}$ (Hewison, 2010). In addition, vitamin $D$ deficiency is prevalent in multiple autoimmune diseases, such as multiple sclerosis, type 1 diabetes, systemic lupus erythematosus, and alopecia areata, and it is highly associated with the risk of autoimmunity (Yang et al., 2013, Lin, Meng and Song, 2019). Vitamin D has been implicated in prevention and protection from autoimmune diseases by immunomodulation of macrophage, dendritic cell, and $T$ cell responses (Hewison, 2010, Yang et al., 2013).

In the recent years, interest has been given to the mechanobiology of macrophages, which like other immune cells have evolved mechanisms to perceive and respond to the mechanical forces around them (Kim et al., 2019). The cellular functions of tissueresident macrophages and monocyte-derived macrophages are affected by the tissue- 
120 specific microenvironment, which can create many types of mechanical stress on cells 121 (McWhorter, Davis and Liu, 2015, Mennens, van den Dries and Cambi, 2017). Stiffness 122 and topography, which are mechanical properties of the extracellular matrix, regulate 123 the differentiation, proliferation, and function of macrophages such as phagocytosis 124 (Patel et al., 2012). In monocytes, the PIEZO1 mechanotransduction in response to cyclical hydrostatic pressure, results in HIF1a stabilization and secretion of molecules, such as endothelin-1 (EDN1), and neutrophil chemoattractant CXCL2 (Solis et al., 2019). In addition, macrophages in tissues are exposed to alterations of pressure which affect the secretion of cytokines such as IL-6, TNF- $\alpha$ and IL-1 $\beta$, (Ferrier et al., 2000, Mevoy et al., 2002). Other mechanical forces that these cells experience originate from dynamic mechanical loading, such as continuous and cyclic stretch and compression (McWhorter, Davis and Liu, 2015, Mennens, van den Dries and Cambi, 2017). Just like normal monocytes, THP-1 cells have shown to respond to mechanical stressors. For example, in models of atherosclerosis, biomechanical strain on THP-1 cells can induce expression of the class A scavenger receptor, an important lipoprotein receptor in atherogenesis (Yamamoto, Ikeda and Shimada, 2003). In addition, DNA microarray analysis has shown that cyclic mechanical strain in THP-1 cells induces expression of genes, some encoding for inflammatory markers such as IL-8 and IEX1(Yamamoto, Ikeda and Shimada, 2003). In these cells, biomechanical deformation influences the degradation of extracellular matrix, monocyte differentiation, and promotion of atherosclerosis (Yamamoto, Ikeda and Shimada, 2003). In addition, as THP-1 cells differentiate they become adherent, a process which may result in altered mechanosensitivity (Tsuchiya et al., 1982, Schwende et al., 1996). In this study, the cells were mechanically stimulated using $1000 \mathrm{~Hz}$ vibrations. The vibrational stimulation of $1000 \mathrm{~Hz}$ frequency and nano-scale amplitude has been used to study in vitro osteogenic differentiation with successful results (Nikukar et al., 2013, Pemberton et al., 2015, Tsimbouri, 2015, Robertson et al., 2018), and in this study it was used to investigate any effect it may have on the differentiation of macrophages from THP-1 monocytes. Assessment of macrophage differentiation in response to externally applied vibrational stimuli can provide insights into monocyte mechanosensitivity and enquire the therapeutic effects of vibrational treatments in inflammatory diseases. From a technical point of view, the experiments of this study were designed to give an insight into the differentiation process of THP-1 monocytes into macrophages under different stimulation parameters, compare between treatments, and look into mechanosensor mRNA expression. 


\section{Materials \& Methods}

THP-1 cells (ATCC $尺$ TIB-202 ${ }^{\mathrm{TM}}$ ) were reconstituted from $-80^{\circ} \mathrm{C}$ storage and allowed to recover for 2 weeks in cultures, splitting when confluency reached around $8 \times 10^{5}$ cells $/ \mathrm{mL}$. The culture medium needed for cell growth was composed of RPMI-1640 with L-glutamine (Capricorn Scientific, RPMI-HA), 10 \% Foetal Bovine Serum (FBS) (Gibco, A3160802) and 1\% Antibiotic-Antimycotic 100X mix (Gibco, 15240062). The cells were cultured at $37^{\circ} \mathrm{C}, 5 \% \mathrm{CO}_{2}$ until ready for the experiments.

\section{Experimental set up}

181

182

183

184

185

186

187

188

189

190

191

192

193

194

195

196

197

198

199

The THP-1 cells were collected from T75 flasks (25mL suspension) and pelleted by centrifugation at $1500 \mathrm{rpm}$ for 10 minutes. The experiment involved 4 replicates of untreated cells, 4 replicates of cells treated with 50nM 1,25-dihydroxyvitamin D3 (Sigma-Aldrich, D1530), 4 replicates of cells treated with $1000 \mathrm{~Hz}$ vibrations (amplitude range of $30-60 \mathrm{~nm}$ ), and 4 replicates of cells treated simultaneously with $50 \mathrm{nM} \mathrm{1,25-}$ dihydroxyvitamin D3 and $1000 \mathrm{~Hz}$ stimulation. The cells underwent stimulation for 3 days (72 hours). No medium or vitamin D3 replacement occurred for this duration of time. The cell density per each replicate at the start of the experiment was $1.5 \times 10^{5} \mathrm{cells} / \mathrm{mL}$, in $1 \mathrm{~mL}$ suspension plated on 24-well plates (Thermofisher Scientific, 142475). The experiments took place at $37^{\circ} \mathrm{C}, 5 \% \mathrm{CO}_{2}$, and 95\% air incubator (LEEC 190D $\left.\mathrm{CO}_{2}\right)$.

\section{Preparation of the vibrational device}

Plates (24-well plates) which would be clamped on the bioreactor had magnet sheets (First4Magnets, D-F4MA43MHP) attached 48 hours before the start of the experiment, for better adhesion and removal of air pockets with time. In addition, the vibrational device (nicknamed Nanokicking bioreactor) was incubated at $37^{\circ} \mathrm{C}$ for 2 days prior to the start of experiments, which was the temperature at which the bioreactor was calibrated. Incubation prior to the experiment was also useful for avoiding condensation upon immediate translocation of the bioreactor from room temperature to incubator environment. The experiments took place in fanless incubator LEEC 190D to avoid additional external vibrations. The bioreactor's stability and generated vibrations were 
200

201

202

203

204

205

206

207

208

209

210

211

212

213

214

215

216

217

218

219

220

221

222

223

224

225

226

227

228

229

230

231

232

233

234

235

236

237

238

239

assessed using laser interferometry every 3 months (diagram in Supplemental Figure 1). The platform of the bioreactor was generating vibrations of $1000 \mathrm{~Hz}$ frequency and amplitude range $30-60 \mathrm{~nm}$ at the time of the experiments.

\section{RNA extraction}

The RNA was extracted separately for the suspension and adherent cells. Cell suspension was slowly removed and added to sterile RNase-free $1.5 \mathrm{~mL}$ tubes. The cells in suspension were pelleted by centrifugation at $3000 \mathrm{rpm}$ for 5 minutes. The supernatant was discarded and $1 \mathrm{~mL}$ Trizol reagent (Invitrogen, AM9738) was added to homogenize the pellet. For the adherent cells, $1 \mathrm{~mL}$ Trizol reagent was added directly in the wells. The lysed cells were homogenized using a $25 \mathrm{~g}$ syringe. The RNA extraction from the lysed cells in Trizol solution was done by separating the aqueous phase after addition of $0.2 \mathrm{~mL}$ chloroform and centrifugation at $13000 \mathrm{rpm}$ for 15 minutes at $4^{\circ} \mathrm{C}$. The RNA was washed with isopropanol and $75 \%$ ethanol and stored in $30 \mu \mathrm{L}$ of nuclease-free water (Gibco, 10977035). Quantification of the RNA in $\mathrm{ng} / \mu \mathrm{L}$ was done on Nanodrop 1000, using the RNA nucleic acid program.

\section{DNase treatment}

The DNase treatment was performed following the protocol of DNA-free Kit (Thermofisher Scientific, AM1906), in order to degrade any genomic DNA that contaminated the RNA solutions during extraction. The maximum RNA concentration for each sample was $5 \mu \mathrm{g}$ per $50 \mu \mathrm{L}$ DNase reaction. Removal of genomic DNA contamination allowed efficient detection of amplification during the real-time PCR.

\section{Complementary DNA synthesis}

The synthesis of cDNA was done as instructed on the protocol of High-Capacity cDNA Reverse transcription Kit (Applied Biosystems, 4368814). The reaction was comprised of $10 \mu \mathrm{L}$ of $2 \mathrm{X} \mathrm{RT}$ Mastermix and $10 \mu \mathrm{L}$ of purified RNA solution from the previous step. Reaction was started by warming at $25^{\circ} \mathrm{C}$ for 10 minutes, followed by incubation at $37^{\circ} \mathrm{C}$ for 2 hours for the synthesis of the cDNA, and termination of reaction at $85^{\circ} \mathrm{C}$ for 5 minutes. The newly synthesized cDNA was stored at $-20^{\circ} \mathrm{C}$ until used for PCR reactions.

\section{Real-time PCR}

Real-time PCR was used to quantify gene expression in adherent and suspension THP1 cells. The PCR amplifications were performed in $25 \mu \mathrm{L}$ reactions containing $12.5 \mu \mathrm{L}$ PowerUP SYBR Green Mastermix (Applied Biosystems ${ }^{\mathrm{TM}}$, A25742); 0.5 $\mu \mathrm{L}$ Forward Primer and $0.5 \mu \mathrm{L}$ Reverse Primer for the respective genes, $1 \mu \mathrm{L}$ of cDNA and topped up to $25 \mu \mathrm{L}$ with nuclease free water (Gibco, 10977035).

The primer pair used for amplification of the housekeeper RPL37A were RPL37A forward 5'-ATTGAAATCAGCCAGCACGC-3' and RPL37A reverse 5'AGGAACCACAGTGCCAGATCC-3'. The primer pair used for amplification of the housekeeper ACTB were ACTB forward 5'-ATTGCCGACAGGATGCAGAA-3' and ACTB reverse 5'-GCTGATCCACATCTGCTGGAA-3'. The primer pair used for 
240 amplification of CD36 were CD36 forward 5'-TCACTGCGACATGATTAATGGTACA-3' 241 and CD36 reverse 5'-ACGTCGGATTCAAATACAGCATAGAT-3'. The primer pair used 242 for amplification of CD14 were CD14 forward 5'-ACGCCAGAACCTTGTGAGC-3' and 243 CD14 reverse 5'-GCATGGATCTCCACCTCTACTG-3'. The primer pair for amplification of HLA-DRA were HLA-DRA forward 5'-TAAGGCACATGGAGGTGATG-3' and HLADRA reverse 5'-GTACGGAGCAATCGAAGAGG-3'. The primer pair used for amplification of HLA-DMB were HLA-DMB forward 5'-CTCTCACAGCACCTCAACCA-3' and HLA-DMB reverse 5'-TAGAAGCCCCACACATAGCA-3'. The primer pair used for amplification of PIEZO1 were PIEZO1 forward 5'-CATCTTGGTGGTCTCCTCTGTCT-3' and PIEZO1 reverse 5'-CTGGCATCCACATCCCTCTCATC-3'. The primer pair used for detection of PKD1 were PKD1 forward 5'-CGCCGCTTCACTAGCTTCGAC-3' and PKD1 reverse 5'-ACGCTCCAGAGGGAGTCCAC-3'. The primer pair used for amplification of $P K D 2$ were PKD2 forward 5'-GCGAGGTCTCTGGGGAAC-3' and PKD2 reverse 5'-TACACATGGAGCTCATCATGC-3'. The primer pair used for amplification of NFAT2 were NFAT2 forward 5'-CACTCCTGCTGCCTTACACA-3' and NFAT2 reverse 5'-AAGATGCGAGCATGCGACTA-3'. The primer pair used for amplification of TCF3 were TCF3 forward 5'-TGACCTCCTGGACTTCAGC-3' and TCF3 reverse 5'ACCTGAACCTCCGAACTGC-3'. The primer pair used for amplification of TCF4 were TCF4 forward 5'-AGTGCGATGTTTTCACCTCC-3' and TCF4 reverse 5'CCTGAGCTACTTCTGTCTTC-3'. The primer pair used for the amplification of TCF7L2 were TCF7L2 forward 5'-CCGGGAAAGTTTGGAAGAAG-3' and TCF7L2 reverse 5'ACTGAAAATGGAGGGTTCGG-3'. The primer pair used for amplification of $L E F-1$ were $\angle E F-1$ forward 5'-GACAGTGACCTAATGCACGT-3' and LEF-1 reverse 5'CCACCTTCTGCCAAGAATCT-3'.

264

265

266

267

268

269

270

271

272

273 The primers for TCFs and LEF-1 transcription factors were designed and tested by Dr. Robin Freeburn. Primers amplifying PIEZO1 were designed using the NCBI primer design tool for the mRNA sequence NM_001142864.4, and primers amplifying CD14 were designed similarly for the mRNA sequences NM_001174105.2 (CD14 mRNA transcript variant 4), NM_001040021.3 (CD14 mRNA transcript variant 2), NM_000591.4 (CD14 mRNA transcript variant 1) and NM_001174104.1 (CD14 mRNA transcript variant 3). The primers for NFAT2 were obtained from Dagna et al. (Dagna, Pritchett and Lusso, 2013), primers for HLA-DRA and HLA-DMB were obtained from Ulbricht et al. (Ulbricht et al., 2012), primers for PKD1 and PKD2 were obtained from Dalagiorgou et al. (Dalagiorgou et al., 2013), and primers from CD36, ACTB and 274

275

276

277

278

279 RPL37A were obtained from Maeß et al. (Maeß, Sendelbach and Lorkowski, 2010). The efficiency of primers taken from existing literature has been assessed in published papers (Fukuda, Mitsuoka and Schmid-Schönbein, 2004, Maeß, Sendelbach and Lorkowski, 2010, Ulbricht et al., 2012, Dagna, Pritchett and Lusso, 2013, Dalagiorgou et al., 2013). The primer efficiency was assessed prior to the experiments and was around $97 \%$ for all the investigated genes. Similar PCR efficiency for each primer is necessary 
280 for relative quantification using the $\Delta \Delta \mathrm{C}_{\mathrm{T}}$ method (Livak and Schmittgen, 2001). The 281 PCR efficiency was also assessed by melt curve analysis. The collected $C_{T}$ values were 282 used for the $\Delta \Delta \mathrm{C}_{\mathrm{T}}$ relative quantification of expression, comparing the stimulated cells 283 to the untreated controls. The $\triangle \mathrm{C}_{\mathrm{T}}$ was obtained by comparison of $\mathrm{CTs}$ of genes of interest to the mean $\mathrm{C}_{\mathrm{T}}$ of two housekeeping genes RPL37A and ACTB. These

285

286

287

288

289

290

291

292

293

294

295

296

297

298

299

300

301

302

303

304

305

306

307

308

309

310

311

312

313

314

315

316

317

318

319

housekeeping genes are considered to be the best for the analysis of RNA expression in THP-1 cells (Maeß, Sendelbach and Lorkowski, 2010).

\section{Statistical analysis}

The gene expression data are presented as mean of four replicates \pm SEM, with little exception where some particular genes were not detected in all replicates. The analysis of statistical significance between the stimulated cells versus controls, and between each type of stimulation was done using unpaired $T$ test with Welch's correction. Statistical analysis was carried out using GraphPad Prism ${ }^{\circledR}$ version 6 . P values $<0.05$ were accepted as significant.

\section{Results}

\section{Regulation of genes encoding macrophage markers and antigen presenting molecules}

Stimulation with vitamin D3, which also served as a positive control for the induction of differentiation, resulted in upregulation of the $C D 14$ and $C D 36$ mRNA in both adherent and suspension cells (Figure 1, A; Figure 2, A). Vitamin D3 also downregulated the HLA-DRA expression in adherent and suspension cells (Figure 1, A; Figure 2, A). The mRNA of $H L A-D M B$ was upregulated for vitamin D3 stimulation in suspension cells (Figure 1, A). The HLA-DMB was not regulated in response to the vitamin D3 in the adherent cells (Figure 2, A).

The $1000 \mathrm{~Hz}$ stimulation caused upregulation of $C D 36$ and downregulation of $H L A-D M B$ in suspension cells (Figure 1, B), whereas in adherent cells it only downregulated the HLA-DRA (Figure 2, B).

The combined stimulation induced upregulation of $C D 14$ and $C D 36$ in both adherent and suspension cells (Figure 1, C; Figure 2, C). The HLA-DRA was downregulated in both cell types compared to the respective unstimulated control (Figure 1, C; Figure 2, C), whereas $H L A-D M B$ was upregulated in suspension cells (Figure $1, C$ ).

The expression values of $C D 14, C D 36, H L A-D R A$ and $H L A-D M B$ in stimulated cells versus controls are shown in Table 1 and Table 2, for suspension and adherent cells respectively.

A comparison between the treatments was performed for the above genes in suspension (Figure 3 ) and adherent cells (Figure 4). The comparison between treatments is shown in detail in Table 3.

$C D 14$ was upregulated only in response to the vitamin $D 3$, as the mRNA levels were comparable to the cells stimulated by the vitamin only (Figure 3, A; Figure 4, A). 
320 Similarly, the upregulation of $C D 36$ in the adherent cells was only in response to the

321

322

323

324

325

326

327

328

329

330

331

332

333

334

335

336

337

338

339

340

341

342

343

344

345

346

347

348

349

350

351

352

353

354

355

356

357

358

359

vitamin D3 in the combined treatment (Figure 3, A). In suspension cells undergoing the combined treatment, the $1000 \mathrm{~Hz}$ stimulation weakened the upregulation of $C D 36$ by the vitamin D3, which was still higher than the upregulation caused by the $1000 \mathrm{~Hz}$ vibrational stimulation alone (Table 3). In the combined treatment, the $1000 \mathrm{~Hz}$ vibrations also weakened the upregulation of $H L A-D M B$ by the vitamin in the suspension cells (Table 3). Interestingly, the HLA-DRA was downregulated from all treatments at the same level in the adherent cells (Figure 4, A), but only the vitamin downregulated this gene in suspension cells (Figure $3, \mathrm{~A}$; Table 3 ).

\section{Regulation of genes encoding transcription factor}

The stimulation with vitamin D3 downregulated NFAT2 and TCF3 in adherent cells (Figure 2, A). The TCF4 and LEF-1 were downregulated in both adherent and suspension cells stimulated with the vitamin (Figure 1, A; Figure 2, A). The TCF7L2 mRNA was upregulated in response to the stimulation with vitamin D3 in suspension (Figure 1, A), and adherent cells (Figure 2, A).

The $1000 \mathrm{~Hz}$ vibrational stimulation upregulated TCF3 in both adherent and suspension cells compared to the respective controls (Figure 1, B; Figure 2, B). This type of stimulation also downregulated NFAT2 in the adherent cells (Figure 2, B). The mRNA expression of TCF4, TCF7L2 and LEF-1 were not affected by the vibrational stimulation (Figure 1, B; Figure 2, B).

The combined stimulation downregulated NFAT2 in both adherent and suspension cells (Figure 1, C; Figure 2, C). The TCF3 mRNA was downregulated in the adherent cells (Figure 2, C), but upregulated in the suspension cells (Figure 1, C). The TCF4 was downregulated in both cell types, and TCF7L2 was upregulated in both cell types (Figure 1, C; Figure 2, C). The LEF-1 was downregulated in the suspension cells (Figure 1, C).

The expression values of TCF3, TCF $4, T C F 7 L 2$ and LEF-1 in stimulated cells versus controls are also shown in Table 1 and Table 2, for suspension and adherent cells respectively.

A comparison between the treatments was performed for these genes encoding transcription factors in suspension (Figure 3, B) and adherent cells (Figure 4, B), and shown in Table 3.

The NFAT2 mRNA was downregulated in adherent cells for all the treatments, without difference between each other (Figure 4, B). In the suspension cells, the NFAT2 was downregulated only for the combined stimulation (Figure 3, B). In adherent cells, the TCF3 mRNA was downregulated in response to vitamin D3 but upregulated for the $1000 \mathrm{~Hz}$ stimulation. In the adherent cells, the vitamin cancelled the upregulating effect of the $1000 \mathrm{~Hz}$ vibration and downregulated TCF3, at comparable 
360 levels to the cells stimulated with vitamin D3 only (Figure 4, B; Table 3). However, in

361

362

363

364

365

366

367

368

369

370

371

372

373

374

375

376

377

378

379

380

381

382

383

384

385

386

387

388

389

390

391

392

393

394

395

396

397

398

399

suspension cells, the TCF3 upregulation was influenced by the $1000 \mathrm{~Hz}$ vibrations, and the mRNA levels were comparable to the cells stimulated with the $1000 \mathrm{~Hz}$ vibrations alone (Table 3; Figure 3, B).

The TCF4 mRNA was downregulated in response to vitamin D3 stimulation in both suspension and adherent cells. In the combined treatment, TCF 4 was influenced by the vitamin only. The $1000 \mathrm{~Hz}$ did not have any influence on the expression of this gene neither alone nor in combination with the vitamin (Figure 3, B; Figure 4, B). Similarly, the upregulation of TCF7L2 mRNA was influenced only by the vitamin D3 in both adherent and suspension cells, with the $1000 \mathrm{~Hz}$ stimulation having no effect on the cells when applied alone or in combination with the vitamin (Figure 3, B; Figure 4, B).

The mRNA for $L E F-1$ was downregulated in response to vitamin D3 stimulation. In the adherent cells little RNA was obtained for this gene, and no amplification was detected for the $1000 \mathrm{~Hz}$ stimulation (Table 3). This needs to be investigated in the future to explain whether the lack of amplification was due to very low transcripts levels in total RNA, or because of some inhibitory effect that $1000 \mathrm{~Hz}$ vibrations may have. In the suspension cells stimulated with the combined treatment, the $1000 \mathrm{~Hz}$ weakened the downregulating effect of the vitamin $\mathrm{D} 3$, however the vitamin influenced the downregulation (Figure 3, B).

\section{Regulation of genes encoding mechanosensors PIEZO1, PKD1 and PKD2}

The stimulation with the vitamin D3 resulted in upregulation of PKD2 (TRPP2) mRNA in both adherent and suspension cells. The stimulation with vitamin D3 alone did not affect the expression of PIEZO1 or PKD1 (TRPP1) (Figure 1, A; Figure 2, A).

The $1000 \mathrm{~Hz}$ vibrational stimulation resulted in upregulation of PIEZO1 mRNA in both adherent and suspension cells. In the adherent cells, the stimulation downregulated PKD2 mRNA. The vibrational stimulation did not affect PKD1 expression (Figure 1, B Figure 2, B).

The combined treatment resulted in the upregulation of $P K D 2$ mRNA in both adherent and suspension cells. PIEZO1 and PKD1 were not regulated in cells stimulated with the combined treatment (Figure 1, C Figure 2, C).

The expression patterns of $P K D 2$ and PIEZO1 in stimulated cells versus controls are shown in Table 1 and Table 2, for suspension and adherent cells, respectively. A comparison between treatments was performed for these genes encoding mechanosensors in the suspension (Figure 3, C) and adherent cells (Figure 4, C), and shown in Table 3.

The expression of $P K D 2$ was affected only by the vitamin D3, which also cancelled the downregulation effect of the $1000 \mathrm{~Hz}$ in the adherent cells stimulated with the combined treatment (Table 3). 
400 The PIEZO1 upregulation occurred only in response to the stimulation with $1000 \mathrm{~Hz}$ 401 vibrations, but in the combined treatment the vitamin cancelled the upregulating effect of 402 the vibrational stimulation (Table 3). The expression of PKD1 mRNA was not affected 403 by any of the stimulation methods (Table 3 ).

404 A comparison of PIEZO1 expression between adherent and suspension cells stimulated 405 with $1000 \mathrm{~Hz}$ vibrations and the combined treatment was performed (Supplemental 406 Figure 3). The $1000 \mathrm{~Hz}$ vibrations upregulated PIEZO1 stronger in adherent cells, than 407 in the suspension cells (Supplemental Figure 3, A). No difference was observed 408 between the adherent and suspension cells stimulated with the combined treatment 409 (Supplemental Figure 3, B).

410

411

412

413

414

415

416

417

418

419

420

421

422

423

424

425

426

427

428

429

430

431

432

433

434

435

436

437

438

439

\section{Discussion}

\section{TCF/LEF pathway and gene nomenclature}

TCF/LEF pathway plays roles in monocyte and macrophage differentiation (Thiele et al., 2001). It must be mentioned that some confusion exists about the nomenclature of the TCFs. The mammalian TCF/LEF family comprises of four nuclear factors designated TCF7, LEF1, TCF7L1, and TCF7L2, which are also known as TCF1, LEF1, TCF3, and TCF4, respectively (Hrckulak et al., 2016). Confusion also exists between the nomenclature of genes and the corresponding products. For example, a gene called TCF3 (NCBI gene ID: 6929), also known as E2A, encodes a product that is different from TCF3 encoded from TCF7L1 (NCBI Gene ID: 83439). Similarly, TCF4 (NCBI gene ID: 6925), encodes for TCF4 which is a different protein from the TCF4 encoded from TCF7L2 (NCBI Gene ID: 6934). In this experiment, the mRNA investigated belongs to genes TCF3 (E2A), TCF4 (E2-2), TCF7L2 and LEF-1, with the last two investigated in the context of WNT canonical pathways in monocyte-derived macrophages (Malsin et al., 2019). The pathways which involve TCF3 and TCF4 gene products can be complex and are not elucidated in context of monocyte to macrophage differentiation.

\section{Vitamin D3 induced macrophage differentiation and downregulated HLA-DRA}

Vitamin D3 has shown to target multiple monocyte genes and promote monocyte differentiation into macrophages (Nurminen, Seuter and Carlberg, 2019). Similarly, this study demonstrated that vitamin D3 stimulation induced differentiation of THP-1 monocytes into macrophages, when looking at transcriptional regulation of $C D 14, C D 36$ and transcription factors TCF7L2 (encoding TCF4) and LEF-1 (Table, 1; Table 2). 
440 The stimulation with vitamin D3 resulted in upregulation of the CD14 and CD36 mRNA 441 in both adherent and suspension cells. This pattern of regulation for these two genes 442 was expected to occur during macrophage differentiation from monocytes (Zhang et al., 443 1994, Maeß, Sendelbach and Lorkowski, 2010). The CD14 is an important marker of the THP-1 differentiation into macrophages which upregulates strongly upon vitamin D3 stimulation (Schwende et al., 1996, Gocek et al., 2012), as was also observed in this study. Furthermore, $C D 14$ and $C D 36$ are primary target genes for vitamin D3 in THP-1 monocytes (Nurminen, Seuter and Carlberg, 2019). The CD14 and CD36 are proteins involved in macrophage functions. CD14 cooperates with Toll-like receptor 4 (TLR4) to mediate the macrophage immune response to bacterial lipopolysaccharide (LPS)(Zanoni et al., 2011).

452 CD36 is a scavenger receptor which has been associated with M2 polarization and enhanced phagocytosis (Pennathur et al., 2015, Woo et al., 2016). It has been reported that $\mathrm{M} 2$ activation of bone marrow-derived macrophages with IL-4 has resulted in upregulation of CD36 expression, whereas M1 activation with LPS and interferon-y has resulted in downregulation of the receptor (Pennathur et al., 2015). During kidney injury, CD36 is an important phenotypic marker of profibrotic M2 macrophages and a key phagocytic receptor for the clearance of apoptotic cells (Pennathur et al., 2015). Similarly, during the resolution phase of stroke, CD36 macrophages have a reparative role through phagocytosis (Woo et al., 2016). Vitamin D3 downregulated the expression of HLA-DRA in differentiating THP-1 cells (Table, 1; Table 2). HLA-DR has been described as an M1 marker, which is upregulated in THP-1 and monocyte - derived macrophages stimulated with IFNy/LPS, whereas its expression is very low with IL-4/IL-13 stimulation (Yang et al., 2016). The decreased HLA-DR expression in monocytes has also been associated with anti-inflammatory states or immunosuppression. HLA-DR expression is decreased in all monocyte subsets upon IL-10 exposure in vitro and during septic shock (Monneret et al., 2004, Lee et al., 2017), whereas monocytes that have diminished or no HLA-DR expression, called CD14 ${ }^{+} \mathrm{HLA}-\mathrm{DR} \mathrm{R}^{\mathrm{lo} / \mathrm{neg}}$ monocytes, have emerged as important mediators of tumorinduced immunosuppression (Mengos, Gastineau and Gustafson, 2019). Downregulation of the HLA-DR protein has been observed in primary monocytes treated with vitamin D3 (Tokuda and Levy, 1996), as well as in dendritic cells (Ferreira et al., 2015). In dendritic cells, the downregulation of HLA-DR has been suggested to be part of tolerance processes induced by vitamin D3 signaling (Ferreira et al., 2015). The upregulation of $C D 36$ and downregulation of HLA-DRA mRNA by vitamin $\mathrm{D} 3$ in day 3-differentiating THP-1 macrophages, could indicate predisposition for M2 polarization. In addition, vitamin D3 stimulation upregulated the mRNA of HLA-DMB in suspension cells. This molecule is important for antigen loading of the MHC class II by removal of CLIP from HLA-DR (Riberdy et al., 1992, Sloan et al., 1995). In one study, HIV-infected THP-1 monocytes had loss of mRNA for HLA-DR, but the mRNAs for HLA-DM 
480

481

482

483

484

485

486

487

488

489

490

491

492

493

494

495

496

497

498

499

500

501

502

503

504

505

506

507

508

509

510

511

512

513

514

515

516

517

518

519

continued to be transcribed, showing that genes may have non-corresponding expression patterns (Shao and Sperber, 2002), similar to what was observed in this study.

This study also identified an inverse relationship between TCF7L2 and LEF-1 mRNA regulation during vitamin D3-induced macrophage differentiation. The TCF7L2 (encoding TCF4) in combination with $\beta$-catenin forms a complex that regulates expression of genes in monocytes and it is thus involved in the differentiation process (Thiele et al., 2001, Tickenbrock, 2006, Malsin et al., 2019), whereas LEF-1 facilitates nuclear localization of $\beta$-catenin and enhances proliferation in acute myeloid leukemia cells, including THP-1 cells (Morgan et al., 2019). Therefore, the downregulation of LEF1 and the upregulation of TCF7L2 could indicate decreased proliferation and increased differentiation as THP-1 monocytes become macrophages (Schwende et al., 1996, Thiele et al., 2001, Morgan et al., 2019). The inverse relationship of TCF7L2 and LEF-1 has also been related to shifts in differentiation and proliferation states in other cancer cells (Kriegl et al., 2010, Eichhoff et al., 2011). This pattern of regulation for these two genes can be signature of THP-1 monocyte to macrophage differentiation.

Another transcription factor downregulated in adherent cells in response to the vitamin D3 was NFAT2. The NFATs are important transcription factors for production of proinflammatory cytokines in T and B cells (Macian, 2005), but their roles are not only limited to the adaptive immune cells. It has been showed that the NFATs are required for Toll-like receptor (TLR)-initiated innate immune responses in bone marrow-derived macrophages (Minematsu et al., 2011). In THP-1 monocytes in vitro, the NFAT2 has shown to inhibit the release of high mobility protein box-1 (HMGB1) (Zhao Q et al., 2016), a proinflammatory protein with roles in inflammation and autoimmunity (Magna and Pisetsky, 2014). The suppression of NFAT2 expression by siRNA has resulted in increased HMGB1 in the supernatant of cells (Zhao Q et al., 2016). In T cells, 1,25dihydroxyvitamin D3 and its receptor complex (VDR-RXR) have shown to inhibit NFAT activity (Wöbke, Sorg and Steinhilber, 2014), but its effect on monocytes and NFAT2 mRNA are not known. In this study, the downregulation of NFAT2 mRNA in the adherent cells, which are considered to be in a more advanced stage of differentiation than the suspension cells (Tsuchiya et al., 1982, Schwende et al., 1996)(Supplemental Figure 2), could be related to the production of proinflammatory proteins after the maturation of the monocytes into macrophages.

The vitamin D3 stimulation also downregulated TCF3 (encoding E2A) in adherent cells, and TCF4 (encoding E2-2) in both cell types compared to the respective controls. The roles of the products of these genes are not known in monocyte biology and macrophage differentiation, but as demonstrated in this study they are regulatable upon vitamin D3 stimulation.

The stimulation with vitamin D3 had no effect on the regulation of PIEZO1 or PKD1, but it upregulated PKD2 (TRPP2) mRNA in both suspension and adhesion cells. The roles 
520 of polycystin 2 (product of PKD2) are not known in THP-1 monocytes, but the results of 521 this study suggest that the PKD2 mRNA upregulation can be signature of vitamin D3522 induced differentiation.

523 Monocyte responses to $1000 \mathrm{~Hz}$ vibrational stimulation

524

525

526

527

528

529

530

531

532

533

534

535

536

537

538

539

540

541

542

543

544

545

546

547

548

549

550

551

552

553

554

555

556

557

558

559

The THP-1 monocytes are responsive to mechanical stressors. Biomechanical strain on THP-1 cells can induce expression of the class A scavenger receptor, degradation of extracellular matrix, monocyte differentiation, and promotion of atherosclerosis (Yamamoto, Ikeda and Shimada, 2003). In addition, DNA microarray analysis has shown that cyclic mechanical strain in THP-1 cells induces expression of genes, some encoding for inflammatory markers such as IL-8 and IEX-1 (Yamamoto, Ikeda and Shimada, 2003). Furthermore, upon differentiation, THP-1 cells become adherent (Tsuchiya et al., 1982, Schwende et al., 1996), which may result in altered mechanosensitivity. This study used $1000 \mathrm{~Hz}$ vibrations as artificially applied mechanical stimulation, in order to study the mechanosensitivity of THP-1 monocytes and assess if it could affect macrophage differentiation.

The vibrational $1000 \mathrm{~Hz}$ stimulation resulted in upregulation of PIEZO1 transcripts in both suspension (Table 1) and adhesion cells (Table 2). PIEZO1 channels are considered professional mechanosensory proteins, capable of sensing and converting mechanical stimuli (Zhong et al., 2018). Little is known about the mechanosensory roles of these channels in monocytes and macrophages. RNA expression analysis presented in cell atlas shows PIEZO1 expressed in monocytes and macrophages, as well as in THP-1 cells (Human Protein Atlas, Cell Type RNA, Piezo1). PIEZO2 expression has not been detected in blood cells, including monocytes, whereas its expression in THP-1 cells is negligible (Human Protein Atlas, Cell Type RNA, Piezo2).

In monocytes, PIEZO1 has shown to signal in response to cyclical hydrostatic pressure, resulting in HIF1 $\alpha$ stabilization and secretion of molecules, such as endothelin-1

(EDN1), and neutrophil chemoattractant CXCL2 (Solis et al., 2019). The PIEZO1 signaling to the cyclical pressure has induced inflammation and infiltration of monocytes, which recruit neutrophils in order to clear pulmonary Pseudomonas aeruginosa infection via EDN1 (Solis et al., 2019). In this study, we demonstrated that THP-1 cells upregulate PIEZO1 mRNA in response to $1000 \mathrm{~Hz}$ vibrational stimulation, when applied in isolation. However, the biological significance of such regulation remains to be elucidated. In addition, the PIEZO1 mRNA upregulation in response to the $1000 \mathrm{~Hz}$ vibrations was stronger in the adherent cells that were in contact with the vibrating surface, compared to the floating suspension cells (Supplemental Figure 3, A). This could indicate potential involvement of mechanotransduction for the regulation of PIEZO1 expression in $1000 \mathrm{~Hz}$ vibrated THP-1 monocytes.

The $1000 \mathrm{~Hz}$ stimulation also caused HLA-DRA downregulation in adherent cells like vitamin D3, but when combined with the vitamin it did not show any synergetic effect

Peer) reviewing PDF | (2021:02:58110:1:1:NEW 28 May 2021) 
560 (Table 3). Another gene which was upregulated during the stimulation with $1000 \mathrm{~Hz}$

561

562

563

564

565

566

567

568

569

570

571

572

573

574

575

576

577

578

579

580

581

582

583

584

585

586

587

588

589

590

591

592

593

594

595

596

597

598

vibrations, was TCF3. This gene was upregulated in both suspension and adherent cells (Table 1; Table 2), but the role of this gene and its products are not known in monocytes. The $1000 \mathrm{~Hz}$ vibrations downregulated the NFAT2 mRNA at the same levels as the vitamin D3 in adherent cells (Table 2), and just like the vitamin it did not regulate this gene in suspension cells (Table 1).

The vibrational stimulation had no effect on the regulation of other transcription factors such as TCF4, TCF7L2 and LEF-1, which were influenced by the vitamin D3 only (Table 1; Table 2; Table 3).

The upregulation of PIEZO1 and TCF3 upon the application of the $1000 \mathrm{~Hz}$ stimulation was interesting, but it was not associated with macrophage differentiation, because there was no transcriptional regulation for genes such as CD14, TCF7L2 and LEF-1 which would indicate transition from monocytes to macrophages. The $C D 36$ was upregulated for the $1000 \mathrm{~Hz}$ stimulation in suspension cells. However, in adherent cells, the CD36 mRNA levels were comparable to the unstimulated adherent controls.

\section{The effects of the combined treatment on gene expression and comparison to vitamin D3 and $1000 \mathrm{~Hz}$ vibrations}

The combined treatment induced macrophages differentiation, but the process was influenced mostly by the vitamin D3 (Table 3).

The upregulation of $C D 14$ in suspension and adherent cells undergoing the combined treatment was comparable to cells stimulated with vitamin D3 only (Table 3). The CD36 mRNA was upregulated in the adherent cells at comparable level to the cells stimulated with vitamin D3 only. However, in the suspension cells the $1000 \mathrm{~Hz}$ had slightly weakened the upregulation of $C D 36$ by the vitamin D3. The combination of both stimuli resulted in lower mRNA expression than the stimulation with the vitamin, but higher than the stimulation with the $1000 \mathrm{~Hz}$, hence it could be said that the $1000 \mathrm{~Hz}$ weakened the upregulating effect of the vitamin (Table 3).

Even though when applied in isolation the $1000 \mathrm{~Hz}$ stimulation caused $H L A-D R A$ downregulation in adherent cells at similar levels to vitamin D3, in the combined stimulation it did not show any synergetic effect. The downregulation of HLA-DRA in suspension cells undergoing the combined treatment was comparable to the cells stimulated with the vitamin D3 only, showing that in the combined treatment this gene was influenced only by the vitamin (Table 3 ).

In the suspension cells undergoing the combined treatment, the $1000 \mathrm{~Hz}$ weakened the upregulation of $H L A-D M B$ by the vitamin. When applied in isolation the $1000 \mathrm{~Hz}$ vibrations downregulated $H L A-D M B$, however, in the combined treatment the vitamin overshadowed the effect of the vibrational stimulus and caused upregulation (Table 3 ). 
599 The combined treatment downregulated NFAT2 at comparable levels to both the

600 vitamin D3 and $1000 \mathrm{~Hz}$ treatments when applied alone in the adherent cells. However,

601 in the suspension cells, the $1000 \mathrm{~Hz}$ and the vitamin D3 may have synergistically caused

602 the downregulation of NFAT2 in suspension cells, because the vitamin and the $1000 \mathrm{~Hz}$

603 did not regulate this gene when applied in isolation.

604 The regulation of TCF4 and TCF7L2 in the cells stimulated with the combined treatment 605 was comparable to the cells stimulated with vitamin D3, and the $1000 \mathrm{~Hz}$ stimulation had 606 no effect on these genes in the combined treatment (Table 3), similar to when it was 607 applied in isolation (Table 1; Table 2). The $1000 \mathrm{~Hz}$ vibrations however, weakened the 608 downregulating effect that the vitamin had on the mRNA encoding LEF-1 in the 609 suspension cell. In the adherent cells, the LEF-1 mRNA in stimulated with the combined 610 treatment was comparable to the unstimulated controls, but since the mRNA for this 611 gene was not detected in cell stimulated with vibrations only, comparison could not take 612 place (Table 3).

613 In the presence of the vitamin D3, the effect of $1000 \mathrm{~Hz}$ stimulation on the regulation of

614 PIEZO1 was cancelled in both adherent and suspension cells. Furthermore, in adherent 615 cells, the vitamin D3 cancelled the upregulating effect of $1000 \mathrm{~Hz}$ on the TCF3 and 616 downregulated the gene (Table 2, Table 3). However, in suspension cells the $1000 \mathrm{~Hz}$ 617 stimulation continued to upregulate TCF3 even in the presence of the vitamin (Table 3).

618 This was the only case in which the effects of $1000 \mathrm{~Hz}$ strongly influenced the

619 expression pattern of a gene in the presence of the vitamin.

620

\section{Conclusions}

622 This study demonstrated that the stimulation with $50 \mathrm{nM}$ vitamin D3 for 3 days drives 623 THP-1 macrophage differentiation, as was determined by upregulation of $C D 14, C D 36$ 624 and TCF7L2, and downregulation of $L E F-1$. The differentiation induced by vitamin D3 625 was accompanied by downregulation of HLA-DRA and upregulation of PKD2 mRNA. 626 Other genes that were regulated during vitamin D3-induced macrophage differentiation 627 included TCF3 and TCF4 in both suspension and adherent cells, and NFAT2 in 628 adherent cells. The upregulation of the mechanosensitive non-selective cation channel 629 PKD2 mRNA could suggest a role during THP-1 macrophage differentiation, whereas 630 the upregulation of $C D 36$ and downregulation of HLA-DRA mRNA could be indicative of 631 predisposition for M2 polarization.

632 The vibrational stimulation which was used for the mechanical stimulation of cells did 633 not induce the macrophage differentiation process because there was no transcriptional 634 regulation of $C D 14$ and $T C F / L E F$ transcription factors. However, the $1000 \mathrm{~Hz}$ vibrations 635 influenced upregulation of PIEZO1 and TCF3 in both adherent and suspension cells. 636 Furthermore, in adherent cells, the vibrational stimulation downregulated NFAT2 and 637 HLA-DRA at comparable levels to the vitamin D3 stimulated adherent cells. This 638 indicated that while the $1000 \mathrm{~Hz}$ vibrations did not induce differentiation, they induced 
639 regulation of genes in the THP-1 cells. However, the biological importance of such 640 response remains to be elucidated.

641 In the combined treatment, the $1000 \mathrm{~Hz}$ vibrations interfered with the regulation of some 642 genes by the vitamin D3 but without changing their regulation pattern. The only 643 exception was TCF3 in suspension cells stimulated with the combined treatment, which 644 was upregulated by the $1000 \mathrm{~Hz}$ vibrations against the downregulating influence of the 645 vitamin D3. The biological importance of such interference remains to be elucidated. 646 However, the mRNA regulation patterns of the other genes of interest in the combined 647 treatment were in response to vitamin D3 stimulation.

648 Furthermore, the influence of the $1000 \mathrm{~Hz}$ stimulus in the presence of the vitamin D3 649 was cancelled (e.g. for PIEZO1 in both cell types), overshadowed (e.g. for CD36 in suspension cells), or cancelled and reversed (e.g. PKD2 in adherent cells). This can have implication for the medicinal application of the $1000 \mathrm{~Hz}$ (nano-scale amplitude) vibrations, because in inflamed tissues rich in chemical signals such as cytokines and chemokines, the cells may lose the ability to sense and respond to such mechanical 654 stimulus.

655 Further work is necessary to assess the reproducibility of the observations of this study, especially in response to the $1000 \mathrm{~Hz}$ vibrational stimulation. This study was limited by the technology, which was not provided for repeated runs and further work. Increased replicates, expanded time-points, assessment of protein expression, and use of primary monocytes to compare to THP-1 cell responses, are recommended for future work from the authors of this report. In addition, the effects of different frequencies and of vibrations applied in cyclical short-term patterns remain to be studied, in order to

662 expand our understanding of THP-1 cell responses towards the vibrational stimulation. Overall, this study presents experimental results indicating that the vibrational mechanical forces can be sensed by THP-1 monocytes, but that the chemical ligands such as vitamin D3 remain superior for the induction of macrophage differentiation. 
679

680

681

682

683

684

685

686

687

688

689

690

691

692

\section{Acknowledgements}

694 The authors would like to thank the University of the West of Scotland and Alopecia UK for financially supporting the experiments of this study. The authors would also like to thank Dr Paul Campsie and Prof Stuart Reid for providing a "Nanokick" bioreactor for

697 the vibrational stimulation of the cells, and for access to the interferometer for the

698 assessment of bioreactor's stability.

699

700

701

702

703

704

705

706

707

708

709

710

711

712

713

714

715

716

717

718

\section{References}

Bosshart, H. and Heinzelmann, M. (2016) THP-1 cells as a model for human monocytes. Annals of Translational Medicine. [Online] Vol.4 (21), pp.438-438. Available: http://atm.amegroups.com/article/view/11701/12871.

Chanput, W., Mes, J. J. and Wichers, H. J. (2014) THP-1 cell line: An in vitro cell model for immune modulation approach. International Immunopharmacology. [Online] Vol.23 (1), pp.37-45. Available: https://linkinghub.elsevier.com/retrieve/pii/S1567576914003166.

Dagna, L., Pritchett, J. C. and Lusso, P. (2013) Immunomodulation and immunosuppression by human herpesvirus 6A and 6B. Future virology. [Online] Vol.8 (3), pp.273-287. Available: http://www.ncbi.nlm.nih.gov/pubmed/24163703.

Dalagiorgou, G., Piperi, C., Georgopoulou, U., Adamopoulos, C., Basdra, E. K. and Papavassiliou, A. G. (2013) Mechanical stimulation of polycystin-1 induces human osteoblastic gene expression via potentiation of the calcineurin/NFAT signaling axis. Cellular and Molecular Life Sciences. [Online] Vol.70 (1), pp.167-180. Available: http://link.springer.com/10.1007/s00018-012-1164-5.

Eichhoff, O. M., Weeraratna, A., Zipser, M. C., Denat, L., Widmer, D. S., Xu, M., Kriegl, L., 
719

720

721

722

723

724

725

726

727

728

729

730

731

732

733

734

735

736

737

738

739

740

741

742

743

744

745

746

747

748

749

750

751

752

753

754

755

756

757

758

759

760

761

762

Kirchner, T., Larue, L., Dummer, R. and Hoek, K. S. (2011) Differential LEF1 and TCF4 expression is involved in melanoma cell phenotype switching. Pigment Cell \& Melanoma Research. [Online] Vol.24 (4), pp.631-642. Available: http://doi.wiley.com/10.1111/j.1755148X.2011.00871.x.

Ferreira, G. B., Vanherwegen, A.-S., Eelen, G., Gutiérrez, A. C. F., Van Lommel, L., Marchal, K., Verlinden, L., Verstuyf, A., Nogueira, T., Georgiadou, M., Schuit, F., Eizirik, D. L., Gysemans, C., Carmeliet, P., Overbergh, L. and Mathieu, C. (2015) Vitamin D3 Induces Tolerance in Human Dendritic Cells by Activation of Intracellular Metabolic Pathways. Cell Reports. [Online] Vol.10 (5), pp.711-725. Available: https://linkinghub.elsevier.com/retrieve/pii/S2211124715000261.

Ferrier, G. M., McEvoy, A., Evans, C. E. and Andrew, J. G. (2000) The effect of cyclic pressure on human monocyte-derived macrophages in vitro. The Journal of Bone and Joint Surgery. British Volume. [Online] Vol.82 (5), pp.755-759. Available: http://journals.bmn.com/medline/search/results?uid=MDLN.20417170.

Fukuda, S., Mitsuoka, H. and Schmid-Schönbein, G. W. (2004) Leukocyte fluid shear response in the presence of glucocorticoid. Journal of Leukocyte Biology. [Online] Vol.75 (4), pp.664670. Available: http://doi.wiley.com/10.1189/jlb.1003464.

Gocek, E., Baurska, H., Marchwicka, A. and Marcinkowska, E. (2012) Regulation of Leukemic Cell Differentiation through the Vitamin D Receptor at the Levels of Intracellular Signal Transduction, Gene Transcription, and Protein Trafficking and Stability. Leukemia Research and Treatment. [Online] Vol.2012, pp.1-11. Available:

https://www.hindawi.com/archive/2012/713243/.

Gordon, S. (2007) The macrophage: Past, present and future. European Journal of Immunology. [Online] Vol.37 (S1), pp.S9-S17. Available: http://doi.wiley.com/10.1002/eji.200737638.

Haussler, M. R., Whitfield, G. K., Kaneko, I., Haussler, C. A., Hsieh, D., Hsieh, J.-C. and Jurutka, P. W. (2013) Molecular Mechanisms of Vitamin D Action. Calcified Tissue International. [Online] Vol.92 (2), pp.77-98. Available: http://link.springer.com/10.1007/s00223-0129619-0.

Hewison, M. (2010) Vitamin D and the Immune System: New Perspectives on an Old Theme. Endocrinology and Metabolism Clinics of North America. [Online] Vol.39 (2), pp.365-379. Available: https://linkinghub.elsevier.com/retrieve/pii/S0889852910000125.

Hrckulak, D., Kolar, M., Strnad, H. and Korinek, V. (2016) TCF/LEF Transcription Factors: An Update from the Internet Resources. Cancers. [Online] Vol.8 (7), p.70. Available: http://www.mdpi.com/2072-6694/8/7/70.

Kim, J.-K., Shin, Y. J., Ha, L. J., Kim, D.-H. and Kim, D.-H. (2019) Unraveling the Mechanobiology of the Immune System. Advanced healthcare materials. [Online] Vol.8 (4), p.e1801332. Available: http://doi.wiley.com/10.1002/adhm.201801332.

Kriegl, L., Horst, D., Reiche, J. A., Engel, J., Kirchner, T. and Jung, A. (2010) LEF-1 and TCF4 expression correlate inversely with survival in colorectal cancer. Journal of Translational Medicine. [Online] Vol.8 (1), p.123. Available: https://translationalmedicine.biomedcentral.com/articles/10.1186/1479-5876-8-123.

Lavin, Y., Mortha, A., Rahman, A. and Merad, M. (2015) Regulation of macrophage development and function in peripheral tissues. Nature Reviews Immunology. [Online] Vol.15 (12), pp.731-744. Available: http://www.nature.com/articles/nri3920.

Peer] reviewing PDF | (2021:02:58110:1:1:NEW 28 May 2021) 
763

764

765

766

767

768

769

770

771

772

773

774

775

776

777

778

779

780

781

782

783

784

785

786

787

788

789

790

791

792

793

794

795

796

797

798

799

800

801

802

803

804

805

806

Lee, J., Tam, H., Adler, L., Ilstad-Minnihan, A., Macaubas, C. and Mellins, E. D. (2017) The MHC class II antigen presentation pathway in human monocytes differs by subset and is regulated by cytokines. PLOS ONE. [Online] Vol.12 (8), p.e0183594. Available: https://dx.plos.org/10.1371/journal.pone.0183594.

Lin, X., Meng, X. and Song, Z. (2019) Vitamin D and alopecia areata: possible roles in pathogenesis and potential implications for therapy. American journal of translational research. [Online] Vol.11 (9), pp.5285-5300. Available: http://www.ncbi.nlm.nih.gov/pubmed/31632510.

Livak, K. J. and Schmittgen, T. D. (2001) Analysis of Relative Gene Expression Data Using RealTime Quantitative PCR and the 2- $\Delta \Delta C T$ Method. Methods. [Online] Vol.25 (4), pp.402-408. Available: https://linkinghub.elsevier.com/retrieve/pii/S1046202301912629.

Macian, F. (2005) NFAT proteins: key regulators of T-cell development and function. Nature Reviews Immunology. [Online] Vol.5 (6), pp.472-484. Available: http://www.nature.com/articles/nri1632.

Maeß, M. B., Sendelbach, S. and Lorkowski, S. (2010) Selection of reliable reference genes during THP-1 monocyte differentiation into macrophages. BMC Molecular Biology. [Online] Vol.11 (1), p.90. Available: http://bmcmolbiol.biomedcentral.com/articles/10.1186/14712199-11-90.

Magna, M. and Pisetsky, D. S. (2014) The Role of HMGB1 in the Pathogenesis of Inflammatory and Autoimmune Diseases. Molecular Medicine. [Online] Vol.20 (1), pp.138-146. Available: https://molmed.biomedcentral.com/articles/10.2119/molmed.2013.00164.

Malsin, E. S., Kim, S., Lam, A. P. and Gottardi, C. J. (2019) Macrophages as a Source and Recipient of Wnt Signals. Frontiers in Immunology. [Online] Vol.10. Available: https://www.frontiersin.org/article/10.3389/fimmu.2019.01813/full.

McWhorter, F. Y., Davis, C. T. and Liu, W. F. (2015) Physical and mechanical regulation of macrophage phenotype and function. Cellular and Molecular Life Sciences. [Online] Vol.72 (7), pp.1303-1316. Available: http://link.springer.com/10.1007/s00018-014-1796-8.

Mengos, A. E., Gastineau, D. A. and Gustafson, M. P. (2019) The CD14+HLA-DRlo/neg Monocyte: An Immunosuppressive Phenotype That Restrains Responses to Cancer Immunotherapy. Frontiers in Immunology. [Online] Vol.10. Available: https://www.frontiersin.org/article/10.3389/fimmu.2019.01147/full.

Mennens, S. F. B., van den Dries, K. and Cambi, A. (2017) Role for Mechanotransduction in Macrophage and Dendritic Cell Immunobiology. In: Results and Problems in Cell Differentiation. [Online]. pp.209-242. Available: http://link.springer.com/10.1007/978-3319-54090-0_9.

Mevoy, A., Jeyam, M., Ferrier, G., Evans, C. . and Andrew, J. . (2002) Synergistic effect of particles and cyclic pressure on cytokine production in human monocyte/macrophages: proposed role in periprosthetic osteolysis. Bone. [Online] Vol.30 (1), pp.171-177. Available: http://linkinghub.elsevier.com/retrieve/pii/S8756328201006585.

Minematsu, H., Shin, M. J., Celil Aydemir, A. B., Kim, K.-O., Nizami, S. A., Chung, G.-J. and Lee, F. Y.-I. (2011) Nuclear presence of nuclear factor of activated T cells (NFAT) c3 and c4 is required for Toll-like receptor-activated innate inflammatory response of monocytes/macrophages. Cellular Signalling. [Online] Vol.23 (11), pp.1785-1793. Available: https://linkinghub.elsevier.com/retrieve/pii/S0898656811001859. 
807

808

809

810

811

812

813

814

815

816

817

818

819

820

821

822

823

824

825

826

827

828

829

830

831

832

833

834

835

836

837

838

839

840

841

842

843

844

845

846

847

848

849

850

Monneret, G., Finck, M.-E., Venet, F., Debard, A.-L., Bohé, J., Bienvenu, J. and Lepape, A. (2004) The anti-inflammatory response dominates after septic shock: association of low monocyte HLA-DR expression and high interleukin-10 concentration. Immunology Letters. [Online] Vol.95 (2), pp.193-198. Available:

https://linkinghub.elsevier.com/retrieve/pii/S0165247804001993.

Morgan, R. G., Ridsdale, J., Payne, M., Heesom, K. J., Wilson, M. C., Davidson, A., Greenhough, A., Davies, S., Williams, A. C., Blair, A., Waterman, M. L., Tonks, A. and Darley, R. L. (2019) LEF-1 drives aberrant $\beta$-catenin nuclear localization in myeloid leukemia cells. Haematologica. [Online] Vol.104 (7), pp.1365-1377. Available: http://www.haematologica.org/lookup/doi/10.3324/haematol.2018.202846.

Mosser, D. M. and Edwards, J. P. (2008) Exploring the full spectrum of macrophage activation. Nature Reviews Immunology. [Online] Vol.8 (12), pp.958-969. Available: http://www.nature.com/articles/nri2448.

Neme, A., Seuter, S. and Carlberg, C. (2016) Vitamin D-dependent chromatin association of CTCF in human monocytes. Biochimica et Biophysica Acta (BBA) - Gene Regulatory Mechanisms. [Online] Vol.1859 (11), pp.1380-1388. Available: https://linkinghub.elsevier.com/retrieve/pii/S1874939916301833.

Nikukar, H., Reid, S., Tsimbouri, P. M., Riehle, M. O., Curtis, A. S. G. and Dalby, M. J. (2013) Osteogenesis of Mesenchymal Stem Cells by Nanoscale Mechanotransduction. ACS Nano. [Online] Vol.7 (3), pp.2758-2767. Available: https://pubs.acs.org/doi/10.1021/nn400202j.

Nurminen, V., Neme, A., Ryynänen, J., Heikkinen, S., Seuter, S. and Carlberg, C. (2015) The transcriptional regulator $B C L 6$ participates in the secondary gene regulatory response to vitamin D. Biochimica et Biophysica Acta (BBA) - Gene Regulatory Mechanisms. [Online] Vol.1849 (3), pp.300-308. Available: https://linkinghub.elsevier.com/retrieve/pii/S1874939914002958.

Nurminen, V., Neme, A., Seuter, S. and Carlberg, C. (2019) Modulation of vitamin D signaling by the pioneer factor CEBPA. Biochimica et Biophysica Acta (BBA) - Gene Regulatory Mechanisms. [Online] Vol.1862 (1), pp.96-106. Available: https://linkinghub.elsevier.com/retrieve/pii/S1874939918304152.

Nurminen, V., Seuter, S. and Carlberg, C. (2019) Primary Vitamin D Target Genes of Human Monocytes. Frontiers in Physiology. [Online] Vol.10. Available: https://www.frontiersin.org/article/10.3389/fphys.2019.00194/full.

Patel, N. R., Bole, M., Chen, C., Hardin, C. C., Kho, A. T., Mih, J., Deng, L., Butler, J., Tschumperlin, D., Fredberg, J. J., Krishnan, R. and Koziel, H. (2012) Cell Elasticity Determines Macrophage Function. PLoS ONE. [Online] Vol.7 (9), p.e41024. Available: http://dx.plos.org/10.1371/journal.pone.0041024.

Pemberton, G. D., Childs, P., Reid, S., Nikukar, H., Tsimbouri, P. M., Gadegaard, N., Curtis, A. S. and Dalby, M. J. (2015) Nanoscale stimulation of osteoblastogenesis from mesenchymal stem cells: nanotopography and nanokicking. Nanomedicine. [Online] Vol.10 (4), pp.547560. Available: http://www.futuremedicine.com/doi/10.2217/nnm.14.134.

Pennathur, S., Pasichnyk, K., Bahrami, N. M., Zeng, L., Febbraio, M., Yamaguchi, I. and Okamura, D. M. (2015) The Macrophage Phagocytic Receptor CD36 Promotes Fibrogenic Pathways on Removal of Apoptotic Cells during Chronic Kidney Injury. The American Journal of Pathology. [Online] Vol.185 (8), pp.2232-2245. Available: 
851

852

853

854

855

856

857

858

859

860

861

862

863

864

865

866

867

868

869

870

871

872

873

874

875

876

877

878

879

880

881

882

883

884

885

886

887

888

889

890

891

892

893

894

https://linkinghub.elsevier.com/retrieve/pii/S0002944015002758.

Phillip Koeffler, H., Reichel, H., Bishop, J. E. and Norman, A. W. (1985) $\gamma$-interferon stimulates production of 1,25-dihydroxyvitamin D3 by normal human macrophages. Biochemical and Biophysical Research Communications. [Online] Vol.127 (2), pp.596-603. Available: https://linkinghub.elsevier.com/retrieve/pii/S0006291X85802023.

Riberdy, J. M., Newcomb, J. R., Surman, M. J., Barbosat, J. A. and Cresswell, P. (1992) HLA-DR molecules from an antigen-processing mutant cell line are associated with invariant chain peptides. Nature. [Online] Vol.360 (6403), pp.474-477. Available: http://www.nature.com/articles/360474a0.

Robertson, S. N., Campsie, P., Childs, P. G., Madsen, F., Donnelly, H., Henriquez, F. L., Mackay, W. G., Salmerón-Sánchez, M., Tsimbouri, M. P., Williams, C., Dalby, M. J. and Reid, S. (2018) Control of cell behaviour through nanovibrational stimulation: nanokicking. Philosophical Transactions of the Royal Society A: Mathematical, Physical and Engineering Sciences. [Online] Vol.376 (2120), p.20170290. Available:

https://royalsocietypublishing.org/doi/10.1098/rsta.2017.0290.

Schwende, H., Fitzke, E., Ambs, P. and Dieter, P. (1996) Differences in the state of differentiation of THP-1 cells induced by phorbol ester and 1,25-dihydroxyvitamin D 3. Journal of Leukocyte Biology. [Online] Vol.59 (4), pp.555-561. Available: http://doi.wiley.com/10.1002/jlb.59.4.555.

Seuter, S., Neme, A. and Carlberg, C. (2016) Epigenome-wide effects of vitamin D and their impact on the transcriptome of human monocytes involve CTCF. Nucleic Acids Research. [Online] Vol.44 (9), pp.4090-4104. Available: https://academic.oup.com/nar/articlelookup/doi/10.1093/nar/gkv1519.

Seuter, S., Neme, A. and Carlberg, C. (2017) Epigenomic PU.1-VDR crosstalk modulates vitamin D signaling. Biochimica et Biophysica Acta (BBA) - Gene Regulatory Mechanisms. [Online] Vol.1860 (4), pp.405-415. Available: https://linkinghub.elsevier.com/retrieve/pii/S1874939916302929.

Seuter, S., Neme, A. and Carlberg, C. (2018) ETS transcription factor family member GABPA contributes to vitamin $D$ receptor target gene regulation. The Journal of Steroid Biochemistry and Molecular Biology. [Online] Vol.177, pp.46-52. Available: https://linkinghub.elsevier.com/retrieve/pii/S0960076017302200.

Shao, L. and Sperber, K. (2002) Impaired Regulation of HLA-DR Expression in Human Immunodeficiency Virus-Infected Monocytes. Clinical and Vaccine Immunology. [Online] Vol.9 (4), pp.739-746. Available: https://cvi.asm.org/content/9/4/739.

Shi, C. and Pamer, E. G. (2011) Monocyte recruitment during infection and inflammation. Nature Reviews Immunology. [Online] Vol.11 (11), pp.762-774. Available: http://www.nature.com/articles/nri3070.

Sloan, V. S., Cameron, P., Porter, G., Gammon, M., Amaya, M., Mellins, E. and Zaller, D. M. (1995) Mediation by HLA-DM of dissociation of peptides from HLA-DR. Nature. [Online] Vol.375 (6534), pp.802-806. Available: http://www.nature.com/articles/375802a0.

Solis, A. G., Bielecki, P., Steach, H. R., Sharma, L., Harman, C. C. D., Yun, S., de Zoete, M. R., Warnock, J. N., To, S. D. F., York, A. G., Mack, M., Schwartz, M. A., Dela Cruz, C. S., Palm, N. W., Jackson, R. and Flavell, R. A. (2019) Mechanosensation of cyclical force by PIEZO1 is essential for innate immunity. Nature. [Online] Vol.573 (7772), pp.69-74. Available: 
895

896

897

898

899

900

901

902

903

904

905

906

907

908

909

910

911

912

913

914

915

916

917

918

919

920

921

922

923

924

925

926

927

928

929

930

931

932

933

934

935

936

937

938

http://www.nature.com/articles/s41586-019-1485-8.

Thiele, A., Wasner, M., Müller, C., Engeland, K. and Hauschildt, S. (2001) Regulation and Possible Function of $\beta$-Catenin in Human Monocytes. The Journal of Immunology. [Online] Vol.167 (12), pp.6786-6793. Available: http://www.jimmunol.org/lookup/doi/10.4049/jimmunol.167.12.6786.

Tickenbrock, L. (2006) Wnt signaling regulates transendothelial migration of monocytes. Journal of Leukocyte Biology. [Online] Vol.79 (6), pp.1306-1313. Available: http://doi.wiley.com/10.1189/jlb.0905539.

Tokuda, N. and Levy, R. B. (1996) 1,25-Dihydroxyvitamin D3 Stimulates Phagocytosis but Suppresses HLA-DR and CD13 Antigen Expression in Human Mononuclear Phagocytes. Experimental Biology and Medicine. [Online] Vol.211 (3), pp.244-250. Available: http://ebm.sagepub.com/lookup/doi/10.3181/00379727-211-43967.

Tsimbouri, P. (2015) Adult Stem Cell Responses to Nanostimuli. Journal of Functional Biomaterials. [Online] Vol.6 (3), pp.598-622. Available: http://www.mdpi.com/20794983/6/3/598.

Tsuchiya, S., Gota, Y., Okumura, H., Nakae, S., Konno, T., Tada, K. and Kobayashi, Y. (1982) Induction of Maturation in Cultured Human Monocytic Leukemia Cells by a Phorbol Diester. Cancer Research. Vol.42 (4), pp.1530-6.

Ulbricht, T., Alzrigat, M., Horch, A., Reuter, N., von Mikecz, A., Steimle, V., Schmitt, E., Krämer, O. H., Stamminger, T. and Hemmerich, P. (2012) PML promotes MHC class II gene expression by stabilizing the class II transactivator. The Journal of Cell Biology. [Online] Vol.199 (1), pp.49-63. Available: https://rupress.org/jcb/article/199/1/49/37158/PMLpromotes-MHC-class-II-gene-expression-by.

Wöbke, T. K., Sorg, B. L. and Steinhilber, D. (2014) Vitamin D in inflammatory diseases. Frontiers in Physiology. [Online] Vol.5. Available:

http://journal.frontiersin.org/article/10.3389/fphys.2014.00244/abstract.

Woo, M.-S., Yang, J., Beltran, C. and Cho, S. (2016) Cell Surface CD36 Protein in Monocyte/Macrophage Contributes to Phagocytosis during the Resolution Phase of Ischemic Stroke in Mice. Journal of Biological Chemistry. [Online] Vol.291 (45), pp.2365423661. Available: http://www.jbc.org/lookup/doi/10.1074/jbc.M116.750018.

Yamamoto, K., Ikeda, U. and Shimada, K. (2003) Role of Mechanical Stress in Monocytes / Macrophages: Implications for Atherosclerosis. Current Vascular Pharmacology. [Online] Vol.1 (3), pp.315-319. Available:

http://www.eurekaselect.com/openurl/content.php?genre=article\&issn=1570$1611 \&$ volume $=1 \&$ issue $=3 \&$ spage $=315$.

Yang, C.-Y., Leung, P. S. C., Adamopoulos, I. E. and Gershwin, M. E. (2013) The Implication of Vitamin D and Autoimmunity: a Comprehensive Review. Clinical Reviews in Allergy \& Immunology. [Online] Vol.45 (2), pp.217-226. Available: http://link.springer.com/10.1007/s12016-013-8361-3.

Yang, M., Ma, B., Shao, H., Clark, A. M. and Wells, A. (2016) Macrophage phenotypic subtypes diametrically regulate epithelial-mesenchymal plasticity in breast cancer cells. BMC Cancer. [Online] Vol.16 (1), p.419. Available: https://bmccancer.biomedcentral.com/articles/10.1186/s12885-016-2411-1.

Zanoni, I., Ostuni, R., Marek, L. R., Barresi, S., Barbalat, R., Barton, G. M., Granucci, F. and Kagan, 
939 J. C. (2011) CD14 Controls the LPS-Induced Endocytosis of Toll-like Receptor 4. Cell.

$940 \quad$ [Online] Vol.147 (4), pp.868-880. Available:

941 https://linkinghub.elsevier.com/retrieve/pii/S0092867411012219.

942 Zhang, D. E., Hetherington, C. J., Gonzalez, D. A., Chen, H. M. and Tenen, D. G. (1994) Regulation

943 of CD14 expression during monocytic differentiation induced with 1 alpha,25-

944 dihydroxyvitamin D3. Journal of immunology (Baltimore, Md. : 1950). Vol.153 (7),

945 pp.3276-84.

946 Zhao Q, L, W., J, H. and H., L. (2016) [Role of nuclear factor of activated T cells-2 in high mobility

947

948

949

950

951

952

953 protein box-1 release in human monocytic THP-1 cells in vitro]. Journal of Southern Medical University (Chinese). [Online] Vol.36 (1), pp.8-12. Available: https://www.ncbi.nlm.nih.gov/pubmed/26806731.

Zhong, M., Komarova, Y., Rehman, J. and Malik, A. B. (2018) Mechanosensing Piezo channels in tissue homeostasis including their role in lungs. Pulmonary Circulation. [Online] Vol.8 (2), p.204589401876739. Available:

954 http://journals.sagepub.com/doi/10.1177/2045894018767393. 


\section{Figure 1}

Gene expression in response to different stimulations in suspension THP-1 cells, compared to the unstimulated suspension THP-1 cells.
A) mRNA regulation in response to stimulation with 50nM of 1,25-dihydroxyvitamin D3. B) mRNA regulation in response to $1000 \mathrm{~Hz}$ vibrations (amplitude $30-60 \mathrm{~nm}$ ). C) mRNA regulation in response to the combined vitamin $\mathrm{D}(50 \mathrm{nM})$ and $1000 \mathrm{~Hz}$ (30 - $60 \mathrm{~nm}$ amplitude) vibrations. Data presented as mean of 4 replicates \pm SEM. Statistical analysis between stimulated and control values was assessed by unpaired T test with Welch's correction. P values lower than 0.05 were considered statistically significant. 
A

Stimulation with 50nM vitamin D3

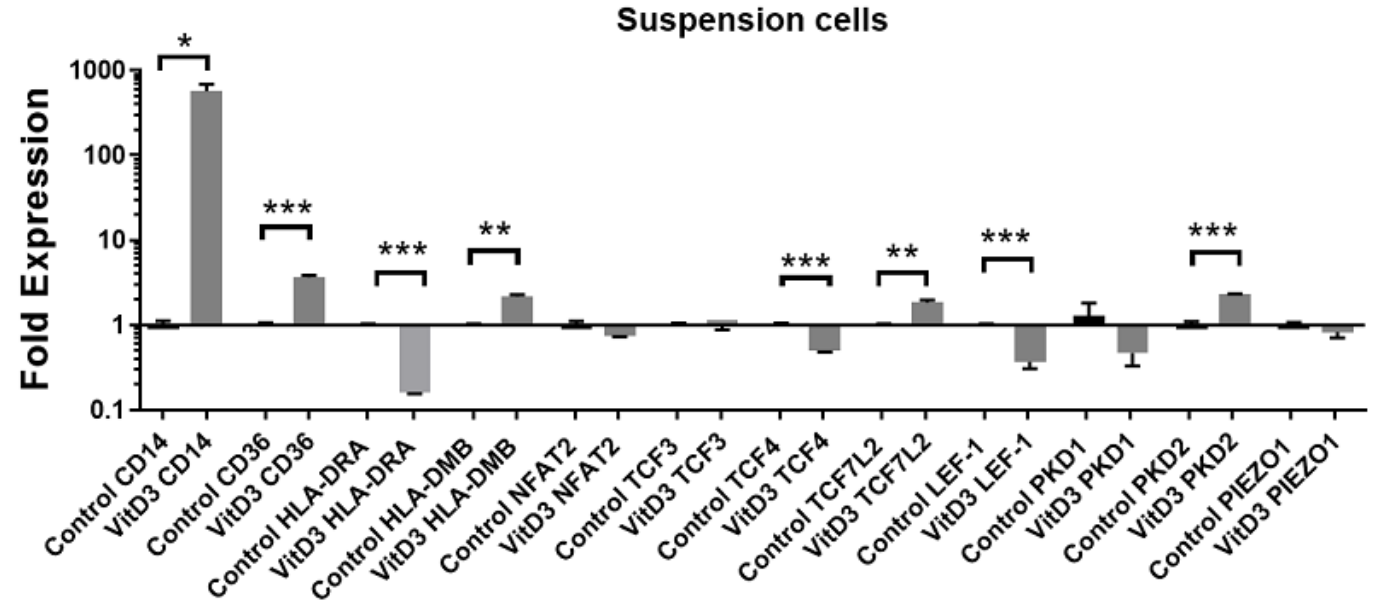

Genes

B

Stimulation with $1000 \mathrm{~Hz}(30-60 \mathrm{~nm})$ vibrations

Suspension cells

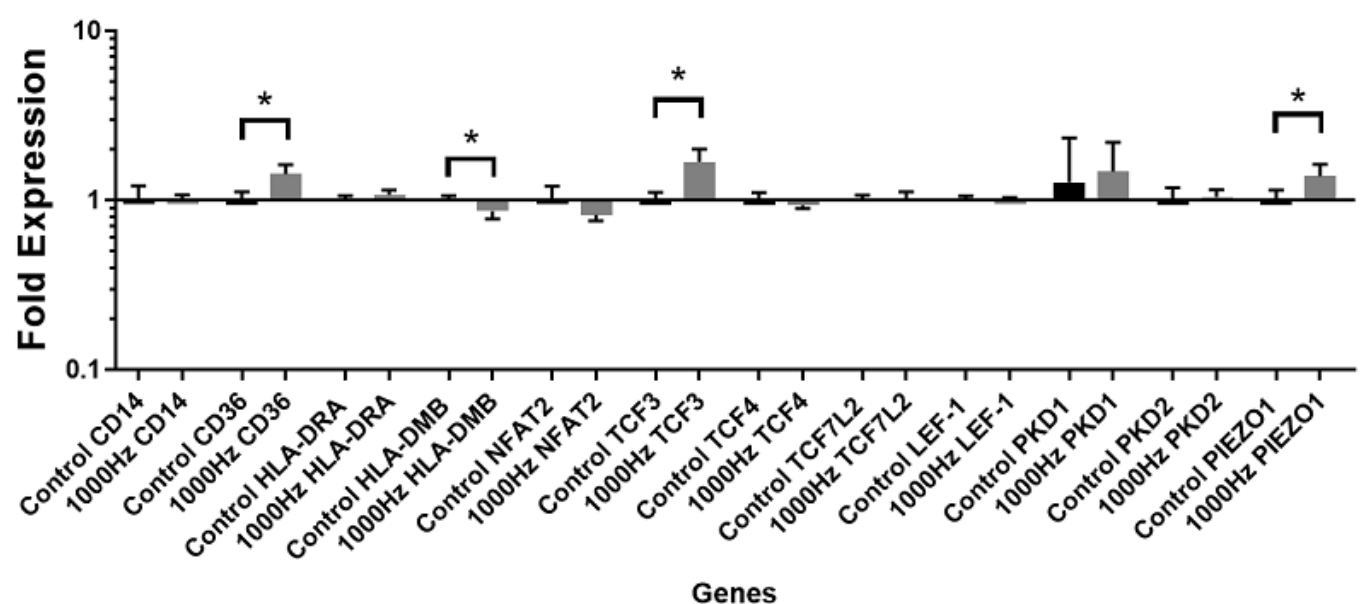

C

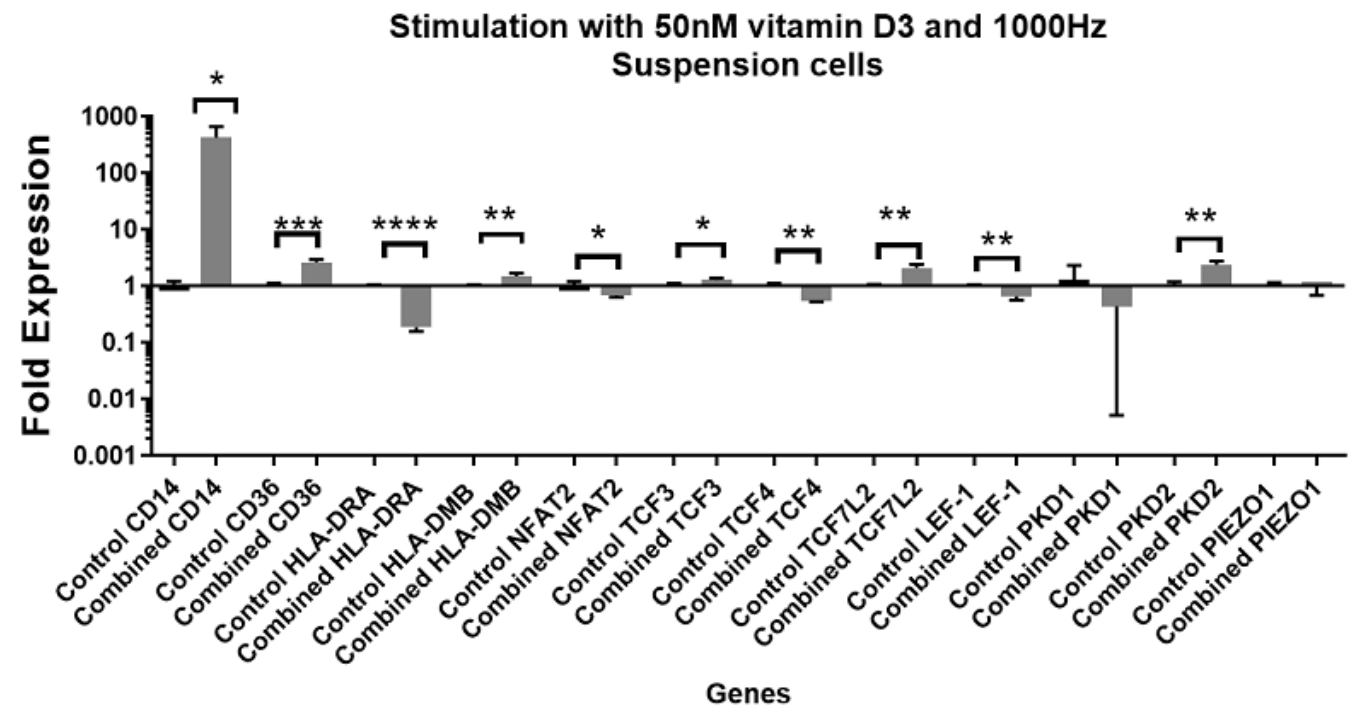




\section{Figure 2}

Gene expression in response to different stimulations in adherent THP-1 cells, compared to the unstimulated adherent THP-1 cells.

A) mRNA regulation in response to stimulation with 50nM of 1,25-dihydroxyvitamin D3. B) mRNA regulation in response to $1000 \mathrm{~Hz}$ vibrations (amplitude $30-60 \mathrm{~nm}$ ). C) mRNA regulation in response to the combined vitamin $\mathrm{D}(50 \mathrm{nM})$ and $1000 \mathrm{~Hz}$ (30 - $60 \mathrm{~nm}$ amplitude) vibrations. Data presented as mean of 4 replicates \pm SEM. Statistical analysis between stimulated and control values was assessed by unpaired T test with Welch's correction. P values lower than 0.05 were considered statistically significant. 
A

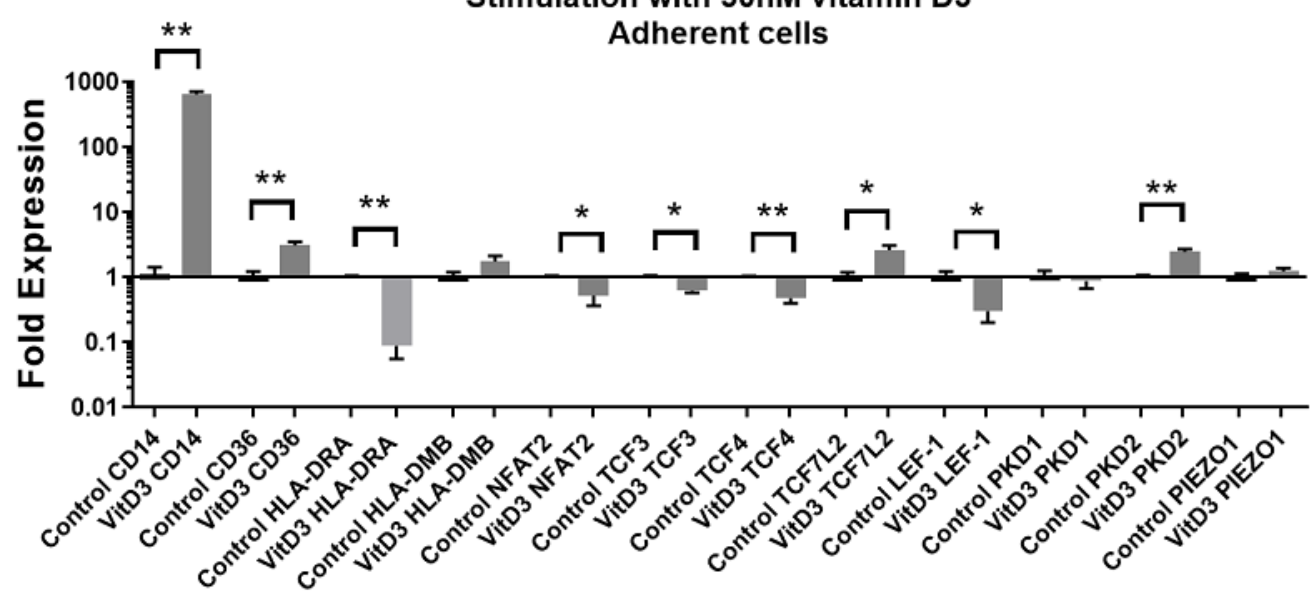

Genes

B

Stimulation with $1000 \mathrm{~Hz}(30-60 \mathrm{~nm})$ vibrations Adherent cells
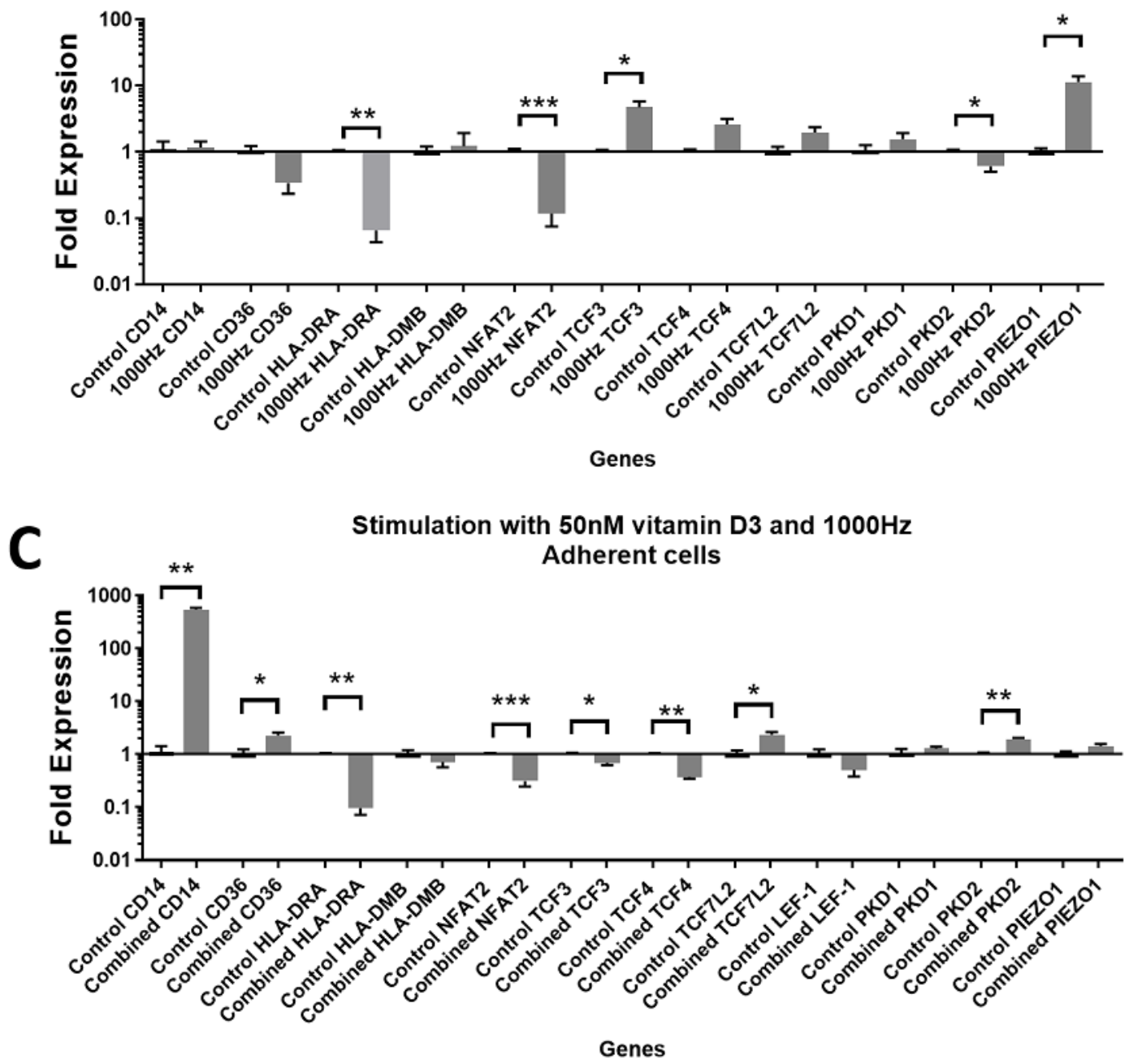
Figure 3

Comparison of fold change values for different genes between the treatments in stimulated THP-1 suspension cells.

Each treatment values were compared to the others using unpaired T test with Welch's correction. P values lower than 0.05 were considered statistically significant. Genes investigated encode for markers of macrophage differentiation $(A)$, transcription factors $(B)$, and mechanosensors (C). 


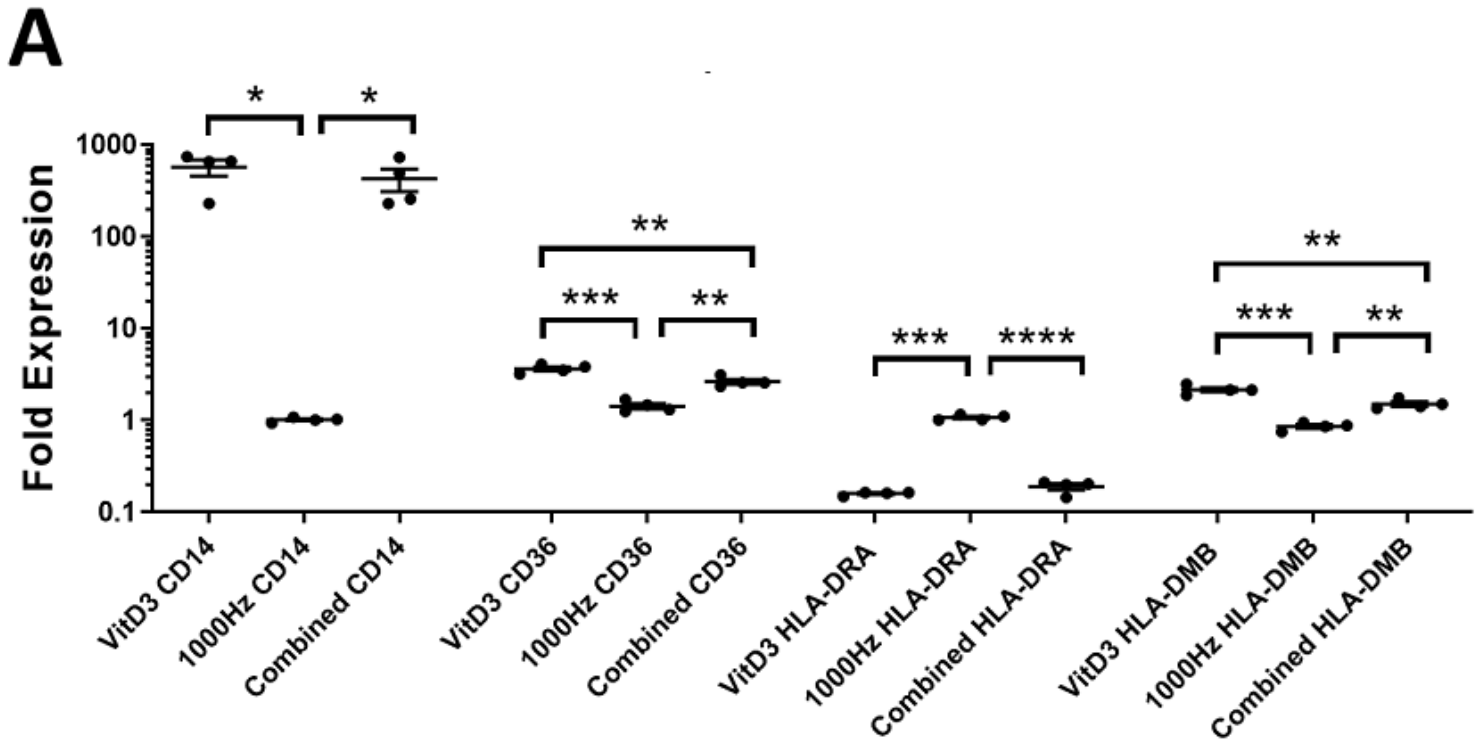

B

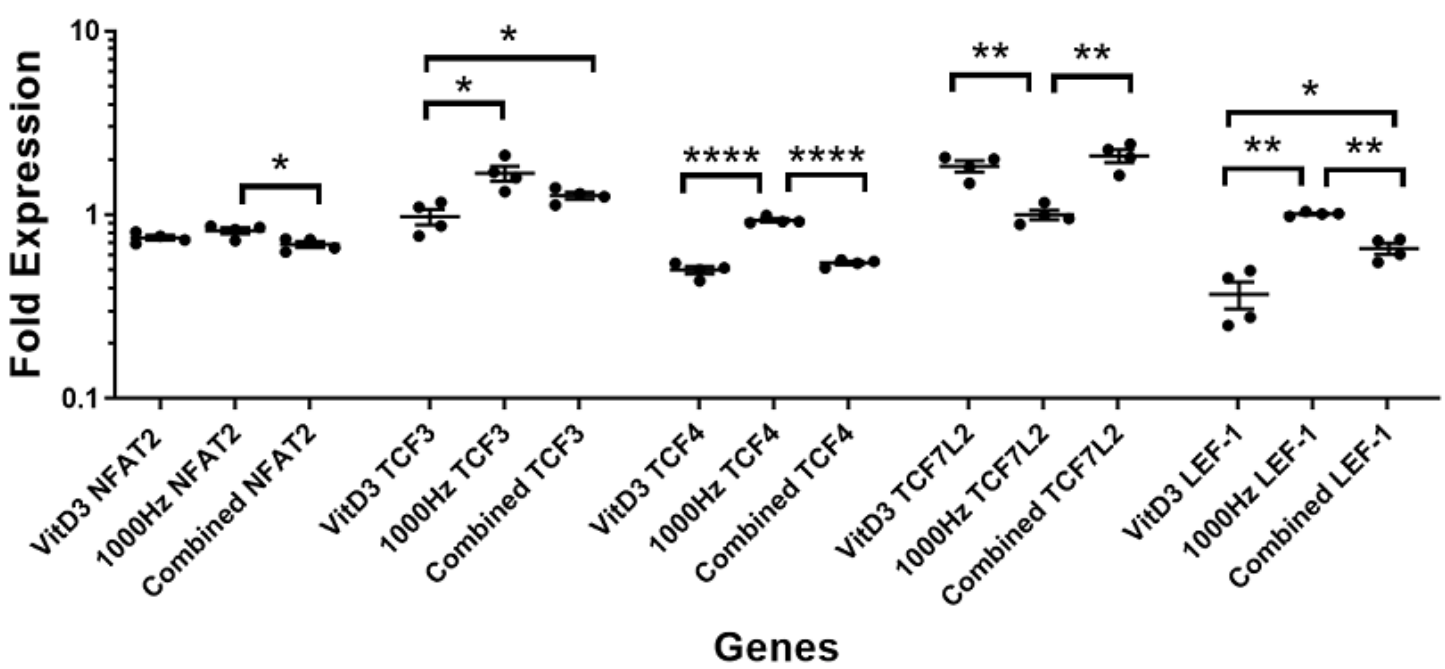

C

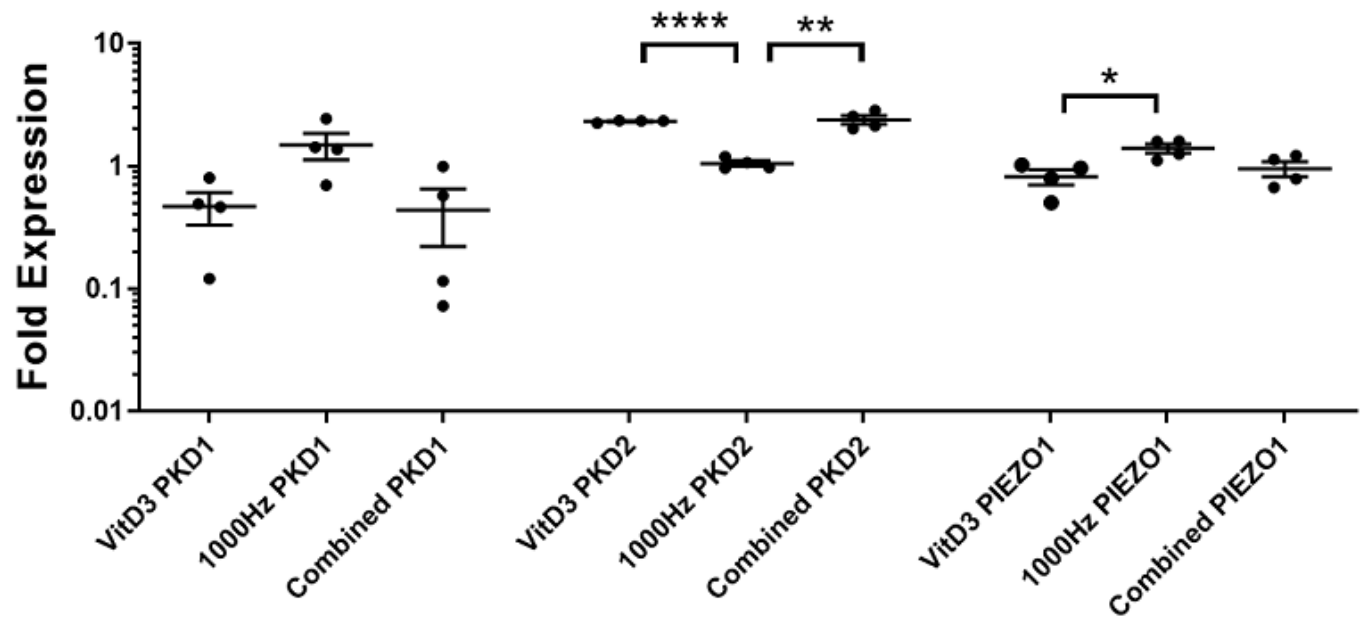

Genes 
Figure 4

Comparison of fold change values for different genes between the treatments in stimulated THP-1 adherent cells.

Each treatment values were compared to the others using unpaired T test with Welch's correction. P values lower than 0.05 were considered statistically significant. Genes investigated encode for markers of macrophage differentiation $(A)$, transcription factors $(B)$, and mechanosensors (C). 
A

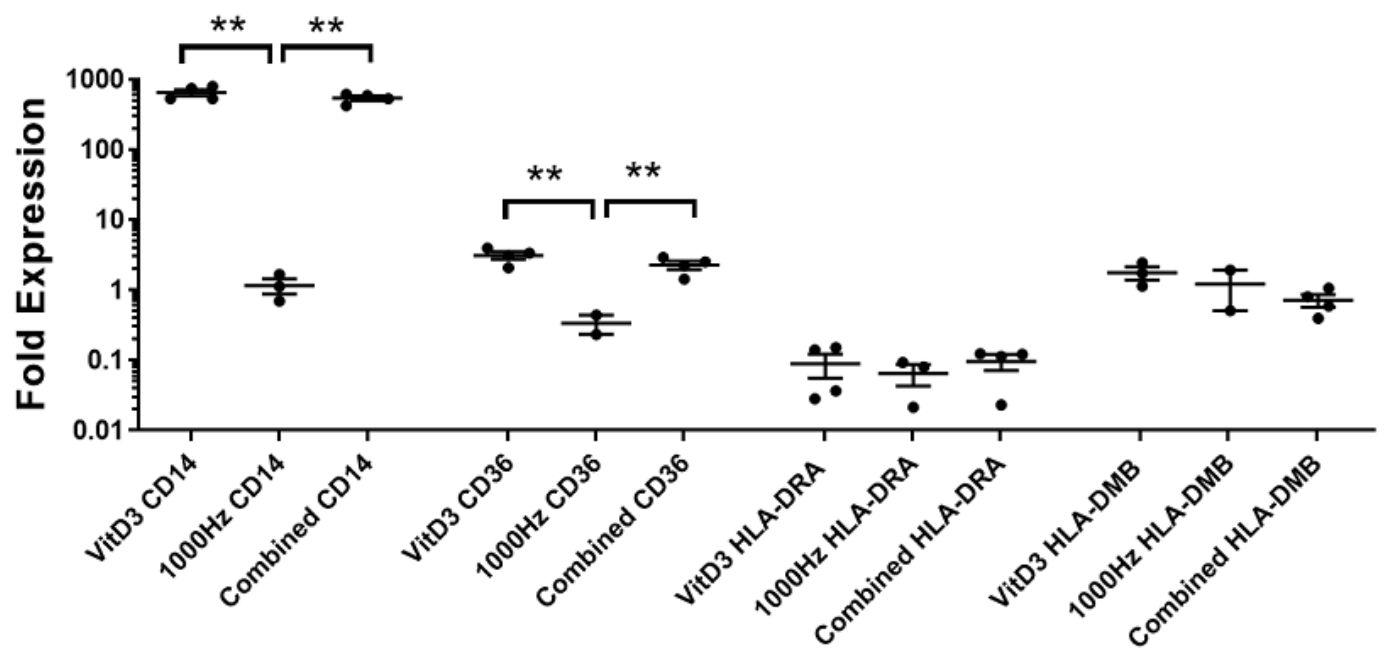

B

Genes

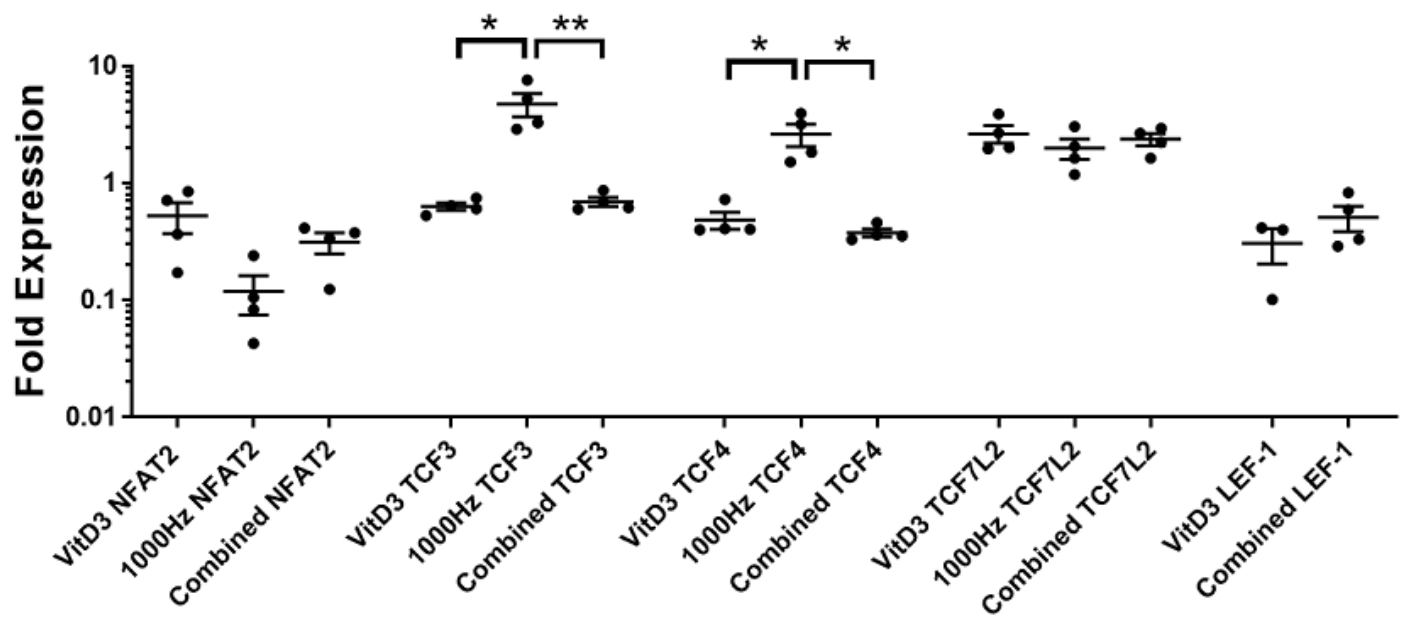

C

Genes

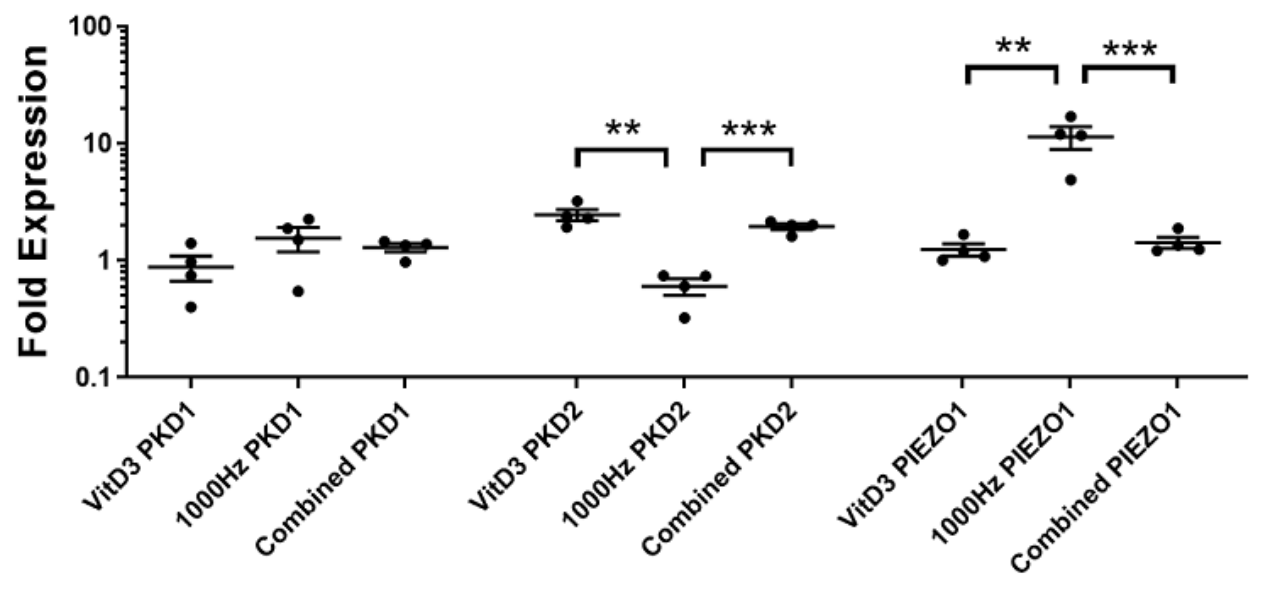

Genes 


\section{Table $\mathbf{1}$ (on next page)}

Expression of genes in stimulated suspension THP-1 cells compared to the unstimulated suspension cells at 72 hours.

Statistical analysis was performed using unpaired T test with Welch's correction. Fold change $\left(2^{-\Delta \Delta c t}\right)$ values higher than 1 indicate upregulation, whereas values between 0 and 1 indicate downregulation of mRNA transcripts in stimulated cells. 


\begin{tabular}{|c|c|c|c|c|}
\hline \multicolumn{5}{|c|}{ THP-1 cells in suspension } \\
\hline Stimulation & mRNA & Roles & $\begin{array}{c}\text { Fold change }\left(2^{\wedge}-\Delta \Delta C T\right) \\
\text { Stimulated cells vs } \\
\text { Control }\end{array}$ & P value \\
\hline \multirow{8}{*}{$\begin{array}{c}50 \mathrm{nM} \\
1,25(\mathrm{OH}) 2 \mathrm{D3} \\
\text { (72 hours) }\end{array}$} & CD14 & Macrophage marker & 573.92 & 0.0161 \\
\hline & CD36 & Macrophage marker & 3.66 & 0.0004 \\
\hline & HLA-DRA & Antigen presentation & 0.16 & 0.0001 \\
\hline & $H L A-D M B$ & Antigen presentation & 2.17 & 0.0016 \\
\hline & PKD2 & $\begin{array}{l}\text { Mechanosensory non- } \\
\text { selective cation channel }\end{array}$ & 2.32 & 0.0004 \\
\hline & TCF4 & $\begin{array}{l}\text { Transcription factor } \\
\text { (unknown roles in } \\
\text { macrophages) }\end{array}$ & 0.5 & 0.001 \\
\hline & TCF7L2 & $\begin{array}{l}\text { Transcription factor } \\
\text { ( proliferation and } \\
\text { differentiation ) }\end{array}$ & 1.85 & 0.0052 \\
\hline & LEF-1 & $\begin{array}{c}\text { Transcription factor } \\
\text { ( proliferation and } \\
\text { differentiation ) }\end{array}$ & 0.37 & 0.0005 \\
\hline \multirow{4}{*}{$\begin{array}{c}\text { Vibrations } \\
1000 \mathrm{~Hz}(30-60 \mathrm{~nm}) \\
(72 \text { hours })\end{array}$} & CD36 & Macrophage marker & 1.43 & 0.013 \\
\hline & $H L A-D M B$ & Antigen presentation & 0.86 & 0.0404 \\
\hline & PIEZO1 & $\begin{array}{c}\text { Mechanosensory } \\
\text { channel }\end{array}$ & 1.39 & 0.0441 \\
\hline & TCF3 & $\begin{array}{l}\text { Transcription factor } \\
\text { (unknown roles in }\end{array}$ & 1.69 & 0.0182 \\
\hline
\end{tabular}




\begin{tabular}{|c|c|c|c|c|}
\hline & & macrophages) & & \\
\hline \multirow{10}{*}{$\begin{array}{c}50 \mathrm{nM} \\
1,25(\mathrm{OH}) 2 \mathrm{D3}+ \\
\text { Vibrations } \\
1000 \mathrm{~Hz}(30-60 \mathrm{~nm}) \\
(72 \text { hours })\end{array}$} & CD14 & Macrophage marker & 428.9 & 0.0359 \\
\hline & CD36 & Macrophage marker & 2.66 & 0.0009 \\
\hline & HLA-DRA & Antigen presentation & 0.19 & $<0.0001$ \\
\hline & $H L A-D M B$ & Antigen presentation & 1.51 & 0.0071 \\
\hline & PKD2 & $\begin{array}{l}\text { Mechanosensory non- } \\
\text { selective cation channel }\end{array}$ & 2.38 & 0.0021 \\
\hline & TCF3 & $\begin{array}{c}\text { Transcription factor } \\
\text { (unknown roles in } \\
\text { macrophages) }\end{array}$ & 1.27 & 0.0142 \\
\hline & TCF4 & $\begin{array}{l}\text { Transcription factor } \\
\text { (unknown roles in } \\
\text { macrophages) }\end{array}$ & 0.55 & 0.0026 \\
\hline & NFAT2 & $\begin{array}{c}\text { Transcription factor } \\
\text { (undefined roles in } \\
\text { macrophages) }\end{array}$ & 0.69 & 0.0434 \\
\hline & TCF7L2 & $\begin{array}{l}\text { Transcription factor } \\
\text { ( proliferation and } \\
\text { differentiation ) }\end{array}$ & 2.1 & 0.0063 \\
\hline & LEF-1 & $\begin{array}{l}\text { Transcription factor } \\
\text { ( proliferation and } \\
\text { differentiation ) }\end{array}$ & 0.66 & 0.0011 \\
\hline
\end{tabular}




\section{Table 2 (on next page)}

Expression of genes in stimulated adherent THP-1 cells compared to the unstimulated adherent cells at 72 hours.

Statistical analysis was performed using unpaired T test with Welch's correction. Fold change $\left(2^{-\Delta \Delta C t}\right)$ values higher than 1 indicate upregulation, whereas values between 0 and 1 indicate downregulation of mRNA transcripts in stimulated cells. 


\begin{tabular}{|c|c|c|c|c|}
\hline \multicolumn{5}{|c|}{ THP-1 cells adhered } \\
\hline Stimulation & mRNA & Roles & $\begin{array}{c}\text { Fold change } \\
\left(2^{\wedge}-\Delta \Delta C T\right) \\
\text { Stimulated cells vs } \\
\text { Control }\end{array}$ & P value \\
\hline \multirow{9}{*}{$\begin{array}{c}50 \mathrm{nM} \\
1,25(\mathrm{OH}) 2 \mathrm{D3} \\
\text { (72 hours) }\end{array}$} & CD14 & Macrophage marker & 650.9 & 0.0026 \\
\hline & CD36 & Macrophage marker & 3.13 & 0.0073 \\
\hline & HLA-DRA & Antigen presentation & 0.09 & 0.0011 \\
\hline & PKD2 & $\begin{array}{l}\text { Mechanosensory non- } \\
\text { selective cation channel }\end{array}$ & 2.47 & 0.0096 \\
\hline & TCF3 & $\begin{array}{c}\text { Transcription factor } \\
\text { (unknown roles in } \\
\text { macrophages) }\end{array}$ & 0.63 & 0.0134 \\
\hline & TCF4 & $\begin{array}{l}\text { Transcription factor } \\
\text { (unknown roles in } \\
\text { macrophages) }\end{array}$ & 0.48 & 0.0032 \\
\hline & NFAT2 & $\begin{array}{l}\text { Transcription factor } \\
\text { (undefined roles in } \\
\text { macrophages) }\end{array}$ & 0.52 & 0.0458 \\
\hline & TCF7L2 & $\begin{array}{l}\text { Transcription factor } \\
\text { ( proliferation and } \\
\text { differentiation ) }\end{array}$ & 2.63 & 0.0313 \\
\hline & LEF-1 & $\begin{array}{c}\text { Transcription factor } \\
\text { (proliferation and } \\
\text { differentiation ) }\end{array}$ & 0.3 & 0.0491 \\
\hline \multirow{3}{*}{$\begin{array}{c}\text { Vibrations } \\
1000 \mathrm{~Hz}(30-60 \mathrm{~nm}) \\
(72 \text { hours })\end{array}$} & HLA-DRA & Antigen presentation & 0.07 & 0.0022 \\
\hline & PIEZO1 & Mechanosensory channel & 11.44 & 0.0247 \\
\hline & PKD2 & $\begin{array}{l}\text { Mechanosensory non- } \\
\text { selective cation channel }\end{array}$ & 0.6 & 0.0236 \\
\hline
\end{tabular}




\begin{tabular}{|c|c|c|c|c|}
\hline & NFAT2 & $\begin{array}{l}\text { Transcription factor } \\
\text { (undefined roles in }\end{array}$ & 0.12 & 0.0004 \\
\hline & TCF3 & $\begin{array}{l}\text { macrophages) } \\
\text { Transcription factor } \\
\text { (unknown roles in }\end{array}$ & 4.73 & 0.04 \\
\hline $\begin{array}{c}50 \mathrm{nM} \\
1,25(\mathrm{OH}) 2 \mathrm{D3}+\end{array}$ & CD14 & $\begin{array}{c}\text { macrophages) } \\
\text { Macrophage marker }\end{array}$ & 542.09 & 0.0011 \\
\hline \multirow{8}{*}{$\begin{array}{c}\text { Vibrations } \\
1000 \mathrm{~Hz}(30-60 \mathrm{~nm}) \\
(72 \text { hours })\end{array}$} & CD36 & Macrophage marker & 2.27 & 0.0227 \\
\hline & HLA-DRA & Antigen presentation & 0.09 & 0.002 \\
\hline & PKD2 & $\begin{array}{l}\text { Mechanosensory non- } \\
\text { selective cation channel }\end{array}$ & 1.95 & 0.0013 \\
\hline & TCF3 & $\begin{array}{l}\text { Transcription factor } \\
\text { (unknown roles in }\end{array}$ & 0.69 & 0.0232 \\
\hline & TCF4 & $\begin{array}{c}\text { macrophages) } \\
\text { Transcription factor } \\
\text { (unknown roles in }\end{array}$ & 0.37 & 0.0016 \\
\hline & NFAT2 & $\begin{array}{l}\text { macrophages) } \\
\text { Transcription factor } \\
\text { (undefined roles in }\end{array}$ & 0.31 & 0.0006 \\
\hline & TCF7L2 & $\begin{array}{l}\text { macrophages) } \\
\text { Transcription factor } \\
\text { (proliferation and }\end{array}$ & 2.36 & 0.0116 \\
\hline & & differentiation ) & & \\
\hline
\end{tabular}




\section{Table 3 (on next page)}

Comparison of THP-1 gene expression between different treatments.

The arrows indicate upregulation or downregulation of the genes when comparing the different stimuli. Statistical analysis was performed using unpaired T test with Welch's correction. 


\begin{tabular}{|c|c|c|c|c|c|c|}
\hline \multirow[t]{2}{*}{ mRNA } & \multicolumn{2}{|c|}{$\begin{array}{c}\text { 50nM Vitamin D3 } \\
\text { vs } \\
1000 \mathrm{~Hz}\end{array}$} & \multicolumn{2}{|c|}{$\begin{array}{c}\text { 50nM Vitamin D3 } \\
\text { vs } \\
\text { 50nM Vitamin D3+1000Hz }\end{array}$} & \multicolumn{2}{|c|}{$\begin{array}{c}\mathbf{5 0 n M} \text { Vitamin } \mathbf{D} \mathbf{3}+\mathbf{1 0 0 0 H z} \\
\text { vs } \\
1000 \mathrm{~Hz}\end{array}$} \\
\hline & Adherent & Suspension & Adherent & Suspension & Adherent & Suspension \\
\hline CD14 & $\begin{array}{l}\text { 个 } 559.5 \text { Fold } \\
(p=0.003)\end{array}$ & $\begin{array}{l}\text { 个 } 564.9 \text { Fold } \\
(p=0.016)\end{array}$ & $\begin{array}{l}\text { No difference } \\
\quad(p=0.24)\end{array}$ & $\begin{array}{l}\text { No difference } \\
\qquad(p=0.41)\end{array}$ & $\begin{array}{l}\uparrow 466.0 \text { Fold } \\
(p=0.001)\end{array}$ & $\begin{array}{c}\text { 个 422.2 Fold } \\
(p=0.036)\end{array}$ \\
\hline CD36 & $\begin{array}{l}\uparrow 9.28 \text { Fold } \\
(p=0.004)\end{array}$ & $\begin{array}{l}\uparrow 2.55 \text { Fold } \\
(p=0.0003)\end{array}$ & $\begin{array}{l}\text { No difference } \\
\qquad(p=0.14)\end{array}$ & $\begin{array}{l}\text { 个 } 1.38 \text { Fold } \\
(p=0.008)\end{array}$ & $\begin{array}{l}\uparrow 6.73 \text { Fold } \\
(p=0.006)\end{array}$ & $\begin{array}{l}\text { 个 } 1.85 \text { Fold } \\
(p=0.002)\end{array}$ \\
\hline $\begin{array}{l}\text { HLA- } \\
\text { DRA }\end{array}$ & $\begin{array}{l}\text { No difference } \\
\qquad(p=0.57)\end{array}$ & $\begin{array}{l}\downarrow 0.15 \text { Fold } \\
(p=0.0001)\end{array}$ & $\begin{array}{l}\text { No difference } \\
\qquad(p=0.87)\end{array}$ & $\begin{array}{l}\text { No difference } \\
\qquad(p=0.14)\end{array}$ & $\begin{array}{l}\text { No difference } \\
\qquad(p=0.39)\end{array}$ & $\begin{array}{l}\downarrow 0.18 \text { Fold } \\
(p<0.0001)\end{array}$ \\
\hline $\begin{array}{l}\text { HLA- } \\
\text { DMB }\end{array}$ & $\begin{array}{l}\text { No difference } \\
\qquad(p=0.58)\end{array}$ & $\begin{array}{l}\text { 个 } 2.51 \text { Fold } \\
(p=0.0008)\end{array}$ & $\begin{array}{l}\text { No difference } \\
\qquad(p=0.09)\end{array}$ & $\begin{array}{l}\text { 个 } 1.43 \text { Fold } \\
(p=0.006)\end{array}$ & $\begin{array}{l}\text { No difference } \\
\qquad(p=0.61)\end{array}$ & $\begin{array}{l}\uparrow 1.75 \text { Fold } \\
(p=0.002)\end{array}$ \\
\hline NFAT2 & $\begin{array}{l}\text { No difference } \\
(p=0.075)\end{array}$ & $\begin{array}{l}\text { No difference } \\
\qquad(p=0.14)\end{array}$ & $\begin{array}{l}\text { No difference } \\
\quad(p=0.28)\end{array}$ & $\begin{array}{l}\text { No difference } \\
\qquad(p=0.15)\end{array}$ & $\begin{array}{l}\text { No difference } \\
(p=0.052)\end{array}$ & $\begin{array}{l}\downarrow 0.84 \text { Fold } \\
(p=0.02)\end{array}$ \\
\hline TCF3 & $\begin{array}{l}\downarrow 0.13 \text { Fold } \\
(p=0.031)\end{array}$ & $\begin{array}{l}\downarrow 0.58 \text { Fold } \\
(p=0.013)\end{array}$ & $\begin{array}{l}\text { No difference } \\
(p=0.44)\end{array}$ & $\begin{array}{l}\downarrow 0.77 \text { Fold } \\
(p=0.045)\end{array}$ & $\begin{array}{l}\downarrow 0.15 \text { Fold } \\
(p=0.009)\end{array}$ & $\begin{array}{l}\text { No difference } \\
\quad(p=0.08)\end{array}$ \\
\hline TCF4 & $\begin{array}{l}\downarrow 0.18 \text { Fold } \\
(p=0.032)\end{array}$ & $\begin{array}{l}\downarrow \quad 0.54 \text { Fold } \\
(p<0.0001)\end{array}$ & $\begin{array}{l}\text { No difference } \\
\qquad(p=0.28)\end{array}$ & $\begin{array}{l}\text { No difference } \\
\qquad(p=0.13)\end{array}$ & $\begin{array}{l}\downarrow 0.14 \text { Fold } \\
(p=0.029)\end{array}$ & $\begin{array}{c}\downarrow 0.59 \text { Fold } \\
(p<0.0001)\end{array}$ \\
\hline TCF7L2 & $\begin{array}{l}\text { No difference } \\
\qquad(p=0.32)\end{array}$ & $\begin{array}{l}\uparrow 1.84 \text { Fold } \\
(p=0.0034)\end{array}$ & $\begin{array}{l}\text { No difference } \\
\qquad(p=0.63)\end{array}$ & $\begin{array}{l}\text { No difference } \\
\qquad(p=0.29)\end{array}$ & $\begin{array}{l}\text { No difference } \\
\qquad(p=0.46)\end{array}$ & $\begin{array}{l}\uparrow 2.09 \text { Fold } \\
(p=0.0047)\end{array}$ \\
\hline LEF-1 & $\mathrm{n} / \mathrm{a}$ & $\begin{array}{l}\downarrow 0.36 \text { Fold } \\
(p=0.0014)\end{array}$ & $\begin{array}{l}\text { No difference } \\
\quad(p=0.3)\end{array}$ & $\begin{array}{l}\downarrow 0.56 \text { Fold } \\
(p=0.011)\end{array}$ & $\mathrm{n} / \mathrm{a}$ & $\begin{array}{l}\downarrow 0.65 \text { Fold } \\
(p=0.0027)\end{array}$ \\
\hline PKD1 & $\begin{array}{l}\text { No difference } \\
\quad(p=0.2)\end{array}$ & $\begin{array}{l}\text { No difference } \\
(p=0.06)\end{array}$ & $\begin{array}{l}\text { No difference } \\
\quad(p=0.15)\end{array}$ & $\begin{array}{l}\text { No difference } \\
(p=0.91)\end{array}$ & $\begin{array}{l}\text { No difference } \\
\quad(p=0.54)\end{array}$ & $\begin{array}{c}\text { No difference } \\
(p=0.055)\end{array}$ \\
\hline PKD2 & $\begin{array}{l}\uparrow 4.09 \text { Fold } \\
(p=0.0036)\end{array}$ & $\begin{array}{c}\uparrow 2.2 \text { Fold } \\
(p<0.0001)\end{array}$ & $\begin{array}{l}\text { No difference } \\
\quad(p=0.16)\end{array}$ & $\begin{array}{l}\text { No difference } \\
\quad(p=0.74)\end{array}$ & $\begin{array}{l}\uparrow 3.24 \text { Fold } \\
(p=0.0001)\end{array}$ & $\begin{array}{c}\uparrow 2.3 \text { Fold } \\
(p=0.0039)\end{array}$ \\
\hline PIEZO1 & $\begin{array}{l}\downarrow 0.11 \text { Fold } \\
(p=0.026)\end{array}$ & $\begin{array}{l}\downarrow 0.59 \text { Fold } \\
(p=0.015)\end{array}$ & $\begin{array}{l}\text { No difference } \\
\quad(p=0.42)\end{array}$ & $\begin{array}{l}\text { No difference } \\
(p=0.478)\end{array}$ & $\begin{array}{l}\downarrow 0.12 \text { Fold } \\
(p=0.027)\end{array}$ & $\begin{array}{l}\text { No difference } \\
\quad(p=0.052)\end{array}$ \\
\hline
\end{tabular}

